\title{
Review \\ Nanomaterials for the Diagnosis and Treatment of Urinary Tract Infections
}

\author{
Maimoona Qindeel ${ }^{1}$, Mahmood Barani ${ }^{2}$ (D) Abbas Rahdar ${ }^{3, *(\mathbb{D}}$, Rabia Arshad ${ }^{1}$ and Magali Cucchiarini $^{4, *(D)}$ \\ 1 Department of Pharmacy, Quaid-i-Azam University, Islamabad 45320, Pakistan; \\ mqindeel81@gmail.com (M.Q.); rabia.arshad@bs.qau.edu.pk (R.A.) \\ 2 Department of Chemistry, Shahid Bahonar University of Kerman, Kerman 76169-14111, Iran; \\ mahmoodbarani7@gmail.com \\ 3 Department of Physics, Faculty of Science, University of Zabol, Zabol 538-98615, Iran \\ 4 Center of Experimental Orthopaedics, Saarland University Medical Center, Kirrbergerstr. Bldg. 37, \\ D-66421 Homburg, Germany \\ * Correspondence: a.rahdar@uoz.ac.ir (A.R.); mmcucchiarini@hotmail.com (M.C.)
}

Citation: Qindeel, M.; Barani, M.;

Rahdar, A.; Arshad, R.; Cucchiarini, M. Nanomaterials for the Diagnosis and Treatment of Urinary Tract Infections. Nanomaterials 2021, 11, 546. https://doi.org/10.3390/nano 11020546

Academic Editor: Andrea Zille

Received: 4 February 2021

Accepted: 17 February 2021

Published: 22 February 2021

Publisher's Note: MDPI stays neutral with regard to jurisdictional claims in published maps and institutional affiliations.

Copyright: (c) 2021 by the authors. Licensee MDPI, Basel, Switzerland. This article is an open access article distributed under the terms and conditions of the Creative Commons Attribution (CC BY) license (https:// creativecommons.org/licenses/by/ $4.0 /)$.

\begin{abstract}
The diagnosis and treatment of urinary tract infections (UTIs) remain challenging due to the lack of convenient assessment techniques and to the resistance to conventional antimicrobial therapy, showing the need for novel approaches to address such problems. In this regard, nanotechnology has a strong potential for both the diagnosis and therapy of UTIs via controlled delivery of antimicrobials upon stable, effective and sustained drug release. On one side, nanoscience allowed the production of various nanomaterial-based evaluation tools as precise, effective, and rapid procedures for the identification of UTIs. On the other side, nanotechnology brought tremendous breakthroughs for the treatment of UTIs based on the use of metallic nanoparticles (NPs) for instance, owing to the antimicrobial properties of metals, or of surface-tailored nanocarriers, allowing to overcome multidrug-resistance and prevent biofilm formation via targeted drug delivery to desired sites of action and preventing the development of cytotoxic processes in healthy cells. The goal of the current study is therefore to present the newest developments for the diagnosis and treatment of UTIs based on nanotechnology procedures in relation to the currently available techniques.
\end{abstract}

Keywords: urinary tract infections; multidrug resistance; surface-tailored nanomedicines; diagnosis; therapy

\section{Introduction}

The urinary system is the most vital organ system, responsible for the drainage of urine and for the maintenance of homeostasis [1] via regulation of the blood volume, pressure, and $\mathrm{pH}$ and of metabolites and electrolytes [2]. The urinary system comprises the kidneys removing wastes and water from the blood in the form of urine [3] that is carried towards the bladder where it gets stored before leaving the body via the urethra [4].

Infections in any part of the urinary system lead to the development of urinary tract infections (UTIs) [4,5]. UTIs are considered as one of the most common infections caused by bacteria, with 150 million people annually affected worldwide [6]. UTIs can be characterized as complicated or uncomplicated [7]. Complicated UTIs are mostly comprised of infections associated with compromised urinary tract and immune system [7]. Common diseases associated with complicated UTIs include neurological impairment-based urinary obstruction, urinary retention, and immunosuppression, renal transplantation, renal failure, pregnancy, or foreign bodies such as biofilms, calculi, catheters, and other devices [8]. Catheter-associated UTIs (CAUTIs) are linked to increased morbidity and mortality and are the most common origin of secondary bloodstream infections $[9,10]$. Noncomplicated UTIs, the most prevalent forms of UTIs, are not based on any neurological, structural, nor physiological defects of the urinary tract [11], characteristically affecting 
women, children, and old patients. They are divided into upper tract UTIs in the nephron (pyelonephritis) and lower tract UTIs (cystitis). The most prominent etiological risk factors for uncomplicated UTIs are chronic UTIs, sexually transmitted UTIs, vaginal infections, diabetes, obesity, and genetics [12,13]. UTIs are mostly caused by both Gram-positive and Gram-negative bacteria and by some fungi. Uropathogenic Escherichia coli (UPEC) is the only common causative agent in the case of both complicated and uncomplicated UTIs [14,15]. Peculiar microbes involved in the pathogenesis of complicated UTIs also include Enterococcus spp., Klebsiella pneumonia, Staphylococcus aureus, Pseudomonas aeruginosa, and Candida spp. [16]. Uncomplicated UTI pathogenesis also steeps progressively due to pathogenic Klebsiella pneumoniae, Staphylococcus saprophyticus, Enterococcus faecalis, group B Streptococcus (GBS), Proteus mirabilis, Pseudomonas aeruginosa, Staphylococcus aureus, and Candida spp. [17]. The basic mechanism involved in the pathogenesis of UTI is the adherence of specific virulence factors residing on bacteria in the urethra followed by colonization and further movement of the pathogen in the bladder using its appendages (flagella and pili) [18]. After attachment of the pathogens in the bladder, complexed host-pathogen interactions then occur, bringing the disease to advance stages. UPEC also develops biofilms-based intracellular bacterial communities (IBCs) as a protection against host immune responses and to overcome bacterial resistance [19]. UTIs result in compromised socioeconomical factors and health, affecting the quality life of affected individuals [20]. Currently, medications used for UTIs include trimethoprim sulfamethoxazole, ciprofloxacin, ampicillin [21], and combined antibiotic therapy to address the multidrugresistance (MDR) features of virulent bacteria [22]. Vaccines targeting bacterial adhesions and bacterial toxins are also available [23,24]. Nevertheless, all these modalities are associated with an increased economic burden, non-patient compliance, and need for targeted delivery, and most importantly with the involvement of virulent factors in bacterial genes causing MDR, with the emergence of even more resistant genes, making the treatment of UTIs particularly arduous [25].

The diagnosis of UTIs initially requires a complete disease and medication history, followed by the physical examination of the pelvic region and the assessment of uropathogens in urine samples using various diagnostic approaches [26]. Laboratory diagnostic tests for UTIs include urinalysis, with an aim to reduce the dose of recommended antibiotics. Microscopic analysis of urine is also performed to diagnose the presence of certain microbes [27]. Culturing method is another standard diagnostic test to detect bacteria [28]. Moreover, the isothermal calorimetry technique is based on the evaluation of the metabolic rates of living microorganisms and microbes. Other conventional and common diagnostic techniques for UTIs include spectroscopic analysis such as Raman spectroscopy, Fourier transform infrared spectroscopy (FTIR), and UV spectroscopy [29,30]. Immunological diagnostic techniques like latex agglutination, enzymatic and coagulation assays are also useful in detecting antibodies and antigens of bacteria in the samples of UTI patients [26]. The diagnosis of UTIs is challenging owing to the vast existence of gaps accompanying over-testing, over-diagnosis, over-treatment, non-specificity, and heterogeneous nature of uropathogens [26,31].

Nanomaterial drug delivery is advantageous compared with conventional therapy because of enhanced specificity in targeting cells, altered pharmacokinetics as well as increased bioavailability, controlled drug release, increased solubilization of hydrophobic drugs, synergistic combinatorial chemistry, and enhancement in drug delivery [32-36]. Nanomaterials can exert their innate antimicrobial action, and synthesizing NPs while conjugating them to antimicrobials may lead to synergistic antibacterial actions, with costeffectiveness and higher stability for a longer period [37]. Antimicrobial NPs for UTIs are mostly based on metals (gold - Au, silver - Ag, titanium NPs) and on metal-based oxides (zinc oxide-ZnO-NPs) [37-44]. All metal and metal-based oxide NP damage the pathogenic microorganisms by various mechanisms of photothermolysis, generating reacting oxygen species (ROS), damaging the cell wall and cell components of pathogens, and interfering with normal enzymatic activities and DNA synthesis [45]. 
The use of metallic NPs has several limitations such as the presence of hazardous wastes, the difficulty in scale-up production, instability, aggregation, and the use of expensive organometallic NPs [46,47]. To overcome these issues, green NP synthesis is being developed based on the use of natural extracts by exploring biological components, essential phytochemicals like flavonoids, terpenoids, alkaloids, phenols, and aldehydes as reducing agents and solvent systems. Moreover, to achieve surface functionalization and receptor-targeted action, the NP surface may be engineered with various biocompatible ligands, resulting in environmental remediation in terms of removing pollutant dyes and heavy metals [48-50].

Several nanoparticle-based antimicrobials are used against UTIs such as surfactantbased vesicles, nanoemulsions, and polymeric NPs like chitosan NPs [51,52]. Chitosan NPs have the ability to bind with negatively charged bacterial membranes and to increase their permeability. Carbon-based NPs and nitric oxide (NO)-releasing NPs can generate reactive nitrogen species (RNS) that also damage the bacterial membrane [53,54].

To overcome the limitations of conventional diagnostic methods for UTIs, a significant number of nanotechnology-based bioassays are highly effective [55-60]. One of these important techniques is optical imaging based on differences in contrast agents between different tissues. The Au nanorods are specific contrast agents, aiming at higher absorbance and scattering light and playing a promising role in damaging bacteria [61]. Similarly, magnetic NPs are required for precise quantification and targeting of pathogenic microbes. Probes based on Au NPs are highly effective and sensitive in detecting microbes [62-67]. Au nanowires arrays get attached with Escherichia coli antibodies to detect the peculiarity of UTIs [68]. MDR bacteria can be distinguished from non-resistant bacteria using Raman spectroscopic fingerprints. Moreover, the metabolic activity and antimicrobial susceptibility of pathogens can be evaluated via Con-A-conjugated supermagnetic iron oxide (SPIO) nanosensors [69]. Keeping in mind all the efforts related to the synthesis of novel nanomaterials and the investigation of their potential in bioapplications [39,40,70-72], we next review the nanomaterials applied to the diagnosis and treatment of UTIs.

\section{Current Approaches for UTI Diagnosis and Biomarkers}

UTIs are the most prevalent infections in persons of any age but especially in elderly people [73-75]. Owing to the high incidence and recurrence of UTIs and to the worldwide rise in antibiotic-resistant bacteria, both the diagnosis and treatment of lower and upper UTIs are becoming more difficult in clinical settings. There are also inexplicable or asymptomatic clinical effects of UTIs. Due to the possibility of septicemia and long-term effects, an early diagnosis of UTIs is critical [76-79].

The diagnosis of UTIs is currently focusing on the evidence of clinical symptoms combined with findings of the nitrite strip test (presence of urinary bacteria) and with an estimation of the number of white blood cells in urine [80,81], as UTI diagnosis in urine culture is time-consuming and costly $[82,83]$. Considerable efforts have been lately directed to evidence novel UTI biomarkers for diagnosis purposes. Several promising serum and urine biomarkers of UTIs like leukocyte esterase, heparin-binding protein, Creactive protein $(\mathrm{CRP})$, procalcitonin, lactoferrin, interleukins, $\mathrm{C}$-reactive protein, elastase alpha (1)-proteinase inhibitor, secretory immunoglobulin A, heparin-binding protein, $\alpha-1$ microglobulin $(\alpha 1 \mathrm{Mg})$, xanthine oxidase, soluble triggering receptor expressed on myeloid cells-1, myeloperoxidase, and tetrazolium nitroblue test (TNB) gained much attention in recent years [81]. The challenging problem is to quantitatively estimate these biomarkers when present at low concentrations. Specific and accurate identification of infectious pathogens in the healthcare industry is the key feature to improved patient care, select empirical treatment, and avoid the transmission of infections. Therefore, various diagnosis methods have been suggested for UTIs. Some may have slower responses, others prolonged response time, and some may have less precision while some may be too costly [84-87]. Nanotechnology may have the potential to overcome these issues and to increase the precision of the existing approaches $[88,89]$. 


\section{Diagnosis of UTIs by Nanotechnology}

UTIs are among the most common bacterial infections, affecting about $50 \%$ of the population at least once in their lives. If UTIs are left undiagnosed and not properly handled, they may have deadly consequences. Additionally, finding a rapid, early, and reliable approach for the identification of uropathogens can be valuable in the clinical phase. Nanoscience is a highly developed area with tremendous scientific interest due to its numerous potential applications in the biomedical area [90]. To overcome the problems caused by traditional diagnosis approaches, nanomedicine can be combined with these methods for better management of UTIs. Nanostructures are more effective in preventing toxicity and resistance and reducing the costs of more traditional methods [91-94]. The current UTI diagnosis methods and nanotechnological approaches are presented in Figure 1.

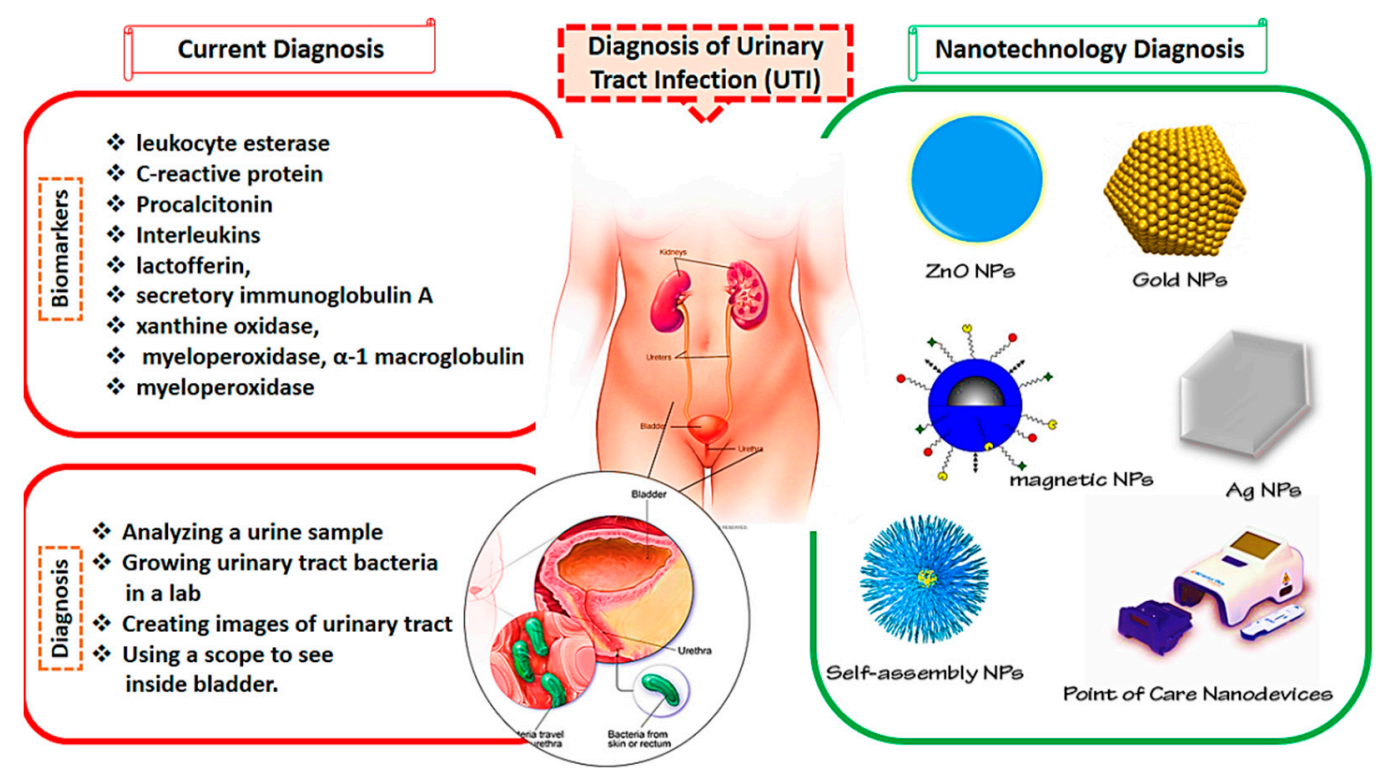

Figure 1. Current methods and nanotechnology approaches for the diagnosis of urinary tract infections (UTIs).

As mentioned above, the existing approaches of urinalysis are complex and timeconsuming and they lack both accuracy and precision [95]. Due to their fast response time and improved precision and accuracy, photoluminescence (PL)-based biosensors attracted more attention in recent years [95-98]. Concerning this, Vasudevan et al. [95] developed a nanosensor based on cysteamine-attached ZnO NPs ( $\mathrm{ZnO}-\mathrm{Cys}$ ) for the identification of N-acyl-homoserine lactones (AHLs) Gram-negative bacteria. AHLs are responsible for the activation of pathogenicity in humans. ZnO NPs were prepared using a microwave-assisted approach with good sensitivity $(97 \%)$ and a linear detection area of $10-120 \mathrm{nM}$ in artificial urine media. The nanosensor was certified using the AHLs created by Pseudomonas aeruginosa (MCC3101) in real-time investigation, supporting their overall sensitivity and specificity.

In an attempt to early diagnose UTIs, a portable bacteria-grabbing nanochip based on surface-enhanced Raman scattering (SERS) was generated by Yang et al. [99] to detect three species of uropathogens (Proteus mirabilis PRM1, Escherichia coli CFT 073, Pseudomonas aeruginosa PAO1) directly from the urine sample medium. The chip was first functionalized with $\mathrm{NH}_{3}{ }^{+}$groups for improved electrostatic adsorption of bacteria with a negative charge. Once the bacteria were captured by the chip, Ag NPs were used to achieve Raman fingerprint spectra of the bacteria. The SERS-based chip detected three species of UTI bacteria at low concentration $\left(10^{5}\right.$ cells $/ \mathrm{mL}$ ) by discriminant analysis (chemometric approach). Additionally, without any sample pre-treatment, the nanochip provided the fingerprint 
information of the bacteria directly from artificial urine and Luria-Bertani (LB) culture medium.

In another study, Alhogail et al. [100] created a rapid, adaptive, and precise colorimetric nanosensor based on magnetic NPs (MNPs) for the identification of Pseudomonas aeruginosa in vivo. The nanoplatform was based on a particular protease substratum assessment of Pseudomonas aeruginosa proteolytic activity. The substrate was covalently attached to MNPs on its N-terminus and connected to an Au sensor surface on its C-terminus. Generally, the Au nanosensor appears black to the naked eye due to coating with MNPs but at proteolysis, the peptide-MNP moieties are cleaved and absorbed by an external magnet. Thereafter, the golden color of the sensor surface becomes observable by the naked eye. In vitro, the biosensor identified the presence of Pseudomonas aeruginosa with 102 colonyforming units $(\mathrm{cfu}) / \mathrm{mL}$ in less than $1 \mathrm{~min}$ while was capable of successfully detecting Pseudomonas aeruginosa in samples from patients.

In resource-limited environments, the point-of-care identification of pathogens in biological samples needs to be rapid, simple, cost-effective, compact, precise. Michael et al. [101] generated a custom-made fidget spinner based on Au NPs that rapidly concentrate the pathogens more than 100 times in $1 \mathrm{~mL}$ samples of undiluted urine for on-device colorimetric identification of bacterial loads and pathogen detection. The system allowed for the on-site, naked-eye identification of infection in urine samples from 39 patients suspected of having UTIs within $50 \mathrm{~min}$. The authors also demonstrated that the system could be applied in 30 clinical samples of UTIs to conduct an antimicrobial susceptibility experiment within $120 \mathrm{~min}$ for the antimicrobial drugs ciprofloxacin and cefazolin. This fidget spinner may be used as an affordable portable system for the rapid concentration and identification of pathogens in urine samples in low-resource settings.

A mobile origami sensor was developed by Adrover-Jaume et al. [102] capable of detecting UTIs caused by Escherichia coli in less than $7 \mathrm{~min}$. A single piece of paper containing antibody-decorated Au NPs was made from an origami nanosensor. If a sample of urine would contain Escherichia coli, the biosensors would produce colored spots on the paper strip that may be quantified by a mobile app by pixel measurements in real-time. The examinations were highly precise and did not crossreact with other uropathogens. In addition, when tested using a panel of 57 urine samples from patients, the biosensors only yielded one false-negative test, demonstrating their strong specificity and sensitivity. This result, along with a quick assessment time and smartphone-based identification, makes such biosensors a useful system to accurately identify UTIs.

Due to their excellent efficiency, low cost, and capacity to identify a broad range of target molecules such as nucleic acids and protein biomarkers, electrochemical nanosensors are well adapted for urinary diagnostics $[103,104]$. For a rapid measurement of the UTI lactoferrin biomarker, Pan et al. [105] created an electrochemical immunosensor (nanoarray of self-assembled monolayer alkanethiolate) from infected serum samples. Lactoferrin is a biomarker of pyuria (white blood cell involvement in urine), an essential UTI symptom [106]. The limit of detection (LOD) of the study was $145 \mathrm{pg} / \mathrm{mL}$ and the simultaneous identification of bacterial nucleic acid (16S rRNA) and of host immune response-associated protein (lactoferrin) on a single sensor array showed multichannel detection of uropathogens and lactoferrin. These findings provided the first interconnected nanoplatform for both quantitative pathogen detection and host immune response assessment.

There are some drawbacks to the commercially available colorimetric urine dipstic for early UTI detection. Identification and quantification of urinary leukocyte esterase (LE) remain unclear for the prediction of UTIs [107]. To solve this problem, Ho et al. [108] proposed a paper-based analytical device (PAD) to detect LE (LE-PAD) as a proof-of-concept UTI quantitative test. The LE-PAD consists of a mixed coating of 3-(N-tosyl-L-alaninyloxy)5-phenylpyrrole (PE) and 1-diazo-2-naphthol-4-sulfonic acid (DAS) accumulated on an Ag film or Ag NPs. The analysis indicated that the LE amount calculated by LE-PADs was descriptive of UTI diagnosis, with an area of 0.875 (95\% confidence interval, 0.704-1.000) under the receiver operating characteristic curve. Using an acceptable cut-off value, the LE- 
UTI PAD's diagnosis specificity and sensitivity were $87.5 \%$ and $92.3 \%$, respectively, while urine dipstic LE positivities were $62.5 \%$ and $76.9 \%$, respectively. The LE-PAD displayed positive and negative probability ratios of 11.38 and 0.14 for UTI diagnosis, indicating that the new LE-PAD may be a valid method.

Novel biosensors have been recently developed based on the unusual plasmonic energy exchange of nanometallic crossed surface-relief gratings (CSRGs). CSRG-based nanosensing, nevertheless, has been restricted to spectroscopic methods and has not exploited its capacity for incorporation with pervasive electronic devices [109]. Nair et al. [109] introduced a novel nanosensor using surface plasmon resonance imaging (SPRi) allowed by CSRGs. The imaging system used two-dimensional nanoplasmonic gratings to facilitate a specific transfer of plasmonic energy between metallic nanomaterials. Finite-difference time-domain (FDTD) simulations confirmed that, due to plasmon resonance at the metal-dielectric interface, CSRG-enabled SPRi was accompanied by an electric field intensity enhancement of about 30 times. The rapid ( $<35 \mathrm{~min})$ and label-free detection of UPEC in phosphate-buffered saline (PBS) and in human urine samples from 103 to $109 \mathrm{cfu} / \mathrm{mL}$ showed the performance of the system for biomedical applications. The platform's LOD was around $100 \mathrm{cfu} / \mathrm{mL}$, i.e., three orders of magnitude below the clinical LOD for UTI detection. The sensing ability of the platform was demonstrated experimentally by the diagnosis of differences in the bulk refractive index (RI), with a sensitivity of $382.2 \mathrm{~nm} / \mathrm{RI}$ units (RIU) and a resolution of $10^{-6}$ RIU. Brayner et al. reported studies of cellular internalization of $\mathrm{ZnO}$ nanoparticles on Escherichia coli bacteria [110].

Table 1 summarizes the most commonly used NP-based sensors for the diagnosis of UTIs.

Table 1. Most commonly used nanoparticle (NP)-based sensors for the diagnosis of UTIs.

\begin{tabular}{ccc}
\hline Nanosensors & Application & References \\
\hline $\begin{array}{c}\text { bacteria-grabbing } \\
\text { nanochip-based on SERS }\end{array}$ & $\begin{array}{c}\text { detection of Proteus mirabilis PRM1, } \\
\text { Escherichia coli CFT 073, and } \\
\text { Pseudomonas aeruginosa PAO1 uropathogens }\end{array}$ & {$[99]$} \\
\hline nanopaper-based systems & $\begin{array}{c}\text { detection of LE (LE-PAD) as a proof-of-concept } \\
\text { for UTI quantitative testing }\end{array}$ & {$[108]$} \\
\hline MNPs identification of & Pseudomonas aeruginosa in vivo & {$[111]$} \\
\hline
\end{tabular}

Abbreviations: SERS, surface-enhanced Raman scattering; MNPs, magnetic nanoparticles; LE, leukocyte esterase; LE-PAD, leukocyte esterase-paper-based analytical device; UTI, urinary tract infection.

\section{Nanomaterials for the Treatment of UTIs}

Compared with conventional antimicrobials, NP-based antimicrobials are easy to fabricate and display prolonged stability, sustained drug release, and higher therapeutic efficacy. NPs that possess antimicrobial properties themselves or increase the therapeutic efficiency of antibiotics are referred nanoantibiotics [112]. Nanoantibiotics kill pathogens through multiple mechanisms including via formation of ROS, interference with energy transduction pathway, inhibition of DNA synthesis, and degradation of the microbial cell wall [113]. Although conventional antimicrobial therapies are effective in inhibiting bacteria, these therapies are ineffective to act against dormant intracellular pathogens due to poor penetration. As a consequence, several pathogens take advantage of this limitation and cause UTI recurrence. Nanoantibiotics possess the capabilities to target the intracellular reservoirs of the pathogens and thus to limit the recurrence of the diseases. Due to the promising advantages of MPs, several antimicrobial-laden NPs such as metals and metal oxides, dendrimers, surfactant-based NPs, and carbon-based nanomaterials have been employed for UTI therapy [114].

\subsection{Metallic NPs with Antimicrobial Activity}

Due to their small size, high surface area, shape, and surface charge, metallic NPs are the most suitable nanocarriers for higher cellular uptake of antimicrobials. The conjuga- 
tion of certain functional groups on their surface increases the cellular interaction of the NPs [115]. Owing to their small size, metallic NPs also exhibit higher cellular penetration than free antimicrobials and are easily absorbed from the blood circulation to the target site. Due to these unique features, several groups employed metallic NPs to achieve efficient delivery of antimicrobials against UTIs [116]. Among the several kinds of metallic NPs, the mechanism of some of the new NPs is still not understood [117-122]. The mechanisms employed by metallic NPs to exert antimicrobial activities are presented in Figure 2. Examples of metallic-based NPs with antimicrobial properties include iron-, Ag-, Au-, Ag oxide-, titanium dioxide-, aluminum oxide-, copper oxide-, and gallium-based NPs [123,124].

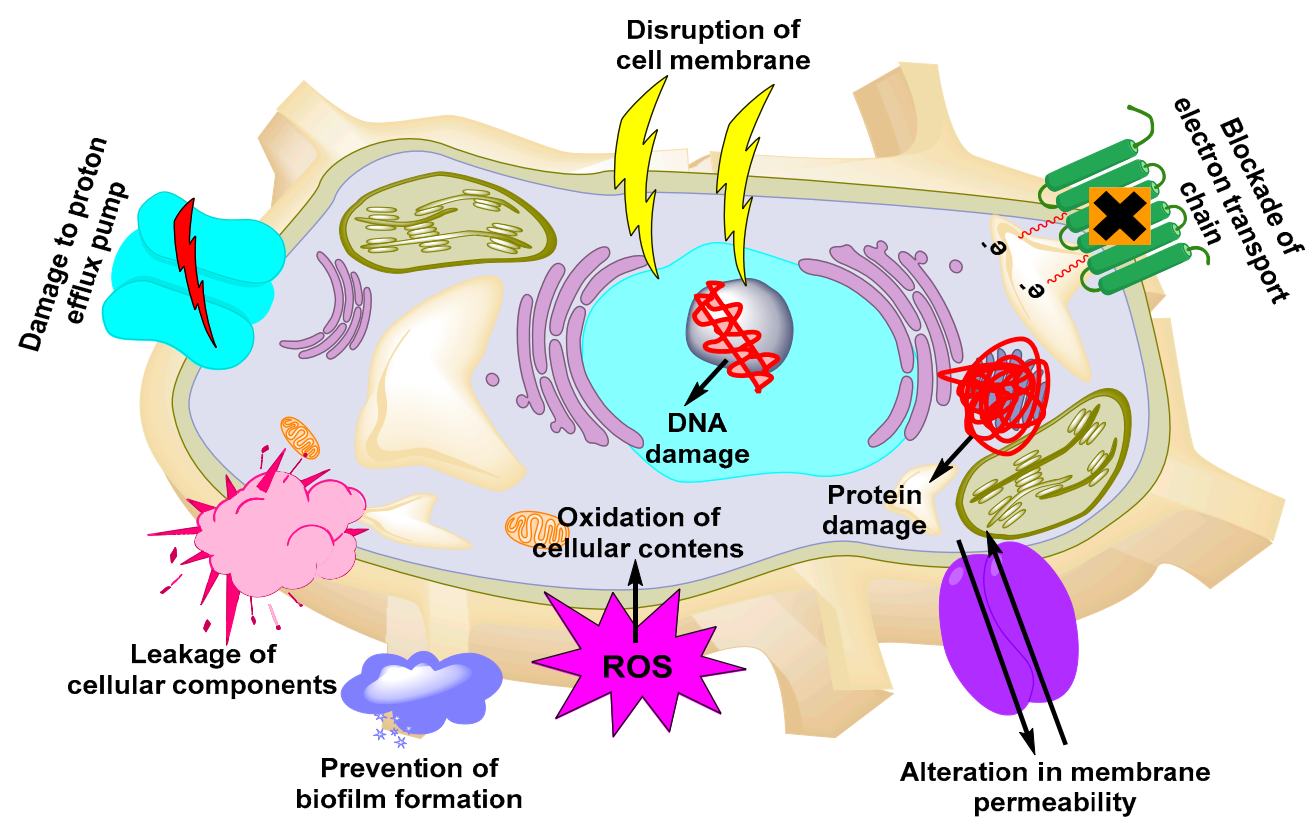

Figure 2. Mechanisms of action of metallic NPs against UTIs.

\subsection{Silver-Based NPS}

When the particle size of $\mathrm{Ag}$ is reduced to the nanorange, it exhibits antibacterial activities against Staphylococcus aureus and Escherichia coli. Ag NPs exhibit antimicrobial properties by affecting the division and respiratory system of microorganisms. Even though the long-term exposure to soluble Ag causes adverse effects on the intestinal tract and kidneys, Ag NPs exhibit negligible effects on human health.

Synthesis of silver-based and other metallic NPs can be achieved through physical, chemical, and biological methods. However, physical and chemical methods are associated with a number of drawbacks including the production of hazardous wastes, the difficulty in scale-up production, and the instability in aggregation while requiring expensive organometallic precursors for the synthesis of NPs. On the other hand, biological methods are regarded as safe procedures, using bacteria as potential biofactories for the synthesis of metallic NPs, making them more "eco-friendly" systems than physical and chemical methods. To exploit the advantages of eco-friendly approach, Divya et al. [125] synthesized eco-friendly Ag NPs with antimicrobial properties against several UTI pathogens and coated them on catheters that overall displayed antibiofilm and antimicrobial properties.

Saleh et al. [126] formulated and investigated the mechanisms of antimicrobial action of two different types of metallic NPs, i.e., Ag-based and titanium dioxide-based NPs, against Proteus vulgaris and Proteus mirabilis, reporting that both kinds of NPs inhibited the microbial species via downregulation of fliL gene expression directly associated with blockade of the movement of the Proteus species. Similarly, Das et al. [127] created Ag NPs loaded with the extract of Oxalis corniculata and observed that compared with pure extract, extract-based Ag NPs exhibited significantly higher antimicrobial activities against both 
Gram-positive and Gram-negative bacterial strains, the leading cause of UTIs. In addition, the authors also reported that the formulations allowed for significantly higher kidney stone dissolution, an effect further increased in the presence of Ag NPs.

Pseudomonas aeruginosa is considered a critical agent for the formation of antibioticresilient biofilms, reducing the therapeutic efficacy of antimicrobials. While Ag NPs are seen as an efficient choice to overcome such events due to their innate bactericidal potential, they may be toxic when used at high concentrations. To tackle such an issue, Bhargava et al. [128] functionalized the surface of the Ag NPs with fucose to increase their interaction with the lectin $\mathrm{B}$ component of the bacterial cell wall. The results of the study demonstrated a superior bactericidal and antibiofilm activity of the functionalized NPs. The key findings of the fluorescence study and confocal laser scanning microscopy revealed that the bactericidal activity was achieved due to the generation of higher ROS and oxidative stress-induced membrane damage. In addition, the functionalized NPs also exhibited a higher antibiofilm-forming potential through the downregulation of several virulence genes.

MDR has become a worldwide issue, showing the urgent need to develop strategies to overcome this critical problem. In this regard, Lopez-Carrizales et al. [129] developed Ag-based NPs to co-deliver amikacin and ampicillin versus single antimicrobial treatment. When ampicillin was administered in combination with Ag NPs against twelve microbial strains of UTIs, the system displayed synergistic effects against one strain, partial synergistic effects against seven strains, and additive impact against four strains. When amikacin was used in combination with Ag NPs, this second system displayed synergistic impact against three strains, partial synergistic impact against eight strains, and exhibited additive effect against another single strain. The cytotoxic effects of both combination approaches at the given concentrations were insignificant relative to the use of single drugs. Based on these results, the authors concluded that MDR may be overcome through a synergistic combined approach. Similarly, El-Batal et al. [130] investigated the potential of Ag- and boron-based NPs against MDR microbial strains. The NPs were formulated through $\gamma$-radiation-induced synthesis of Ag-boron NPs using an eco-friendly approach with polyvinylpyrrolidone as the stabilizing agent. These NPs exhibited zones of inhibition of $20 \mathrm{~mm}, 18 \mathrm{~mm}$, and $16 \mathrm{~mm}$ and biofilm inhibition of $87 \%, 85.3 \%$, and $69.4 \%$ against Candida albicans, Escherichia coli, and Staphylococcus aureus, respectively. Mishra et al. [131] formulated Ag NPs loaded with timber-yielding plant extract, having a particle size less than $100 \mathrm{~nm}$. The antibacterial efficacy of the prepared formulation was evaluated against 11 MDR bacterial strains responsible for UTIs. Compared with the standard gentamicin $(30 \mu \mathrm{g} / \mathrm{mL})$, the prepared nanoformulation $(15 \mu \mathrm{g} / \mathrm{mL})$ significantly reduced the zone of inhibition from 30 to $13 \mathrm{~mm}$. The toxicity of the prepared formulation was also investigated in cultured lymphocytes obtained from umbilical cord blood, showing cell death below $25 \%$, supporting the concept of safely using these systems against MDR UTIs.

Rodríguez-Serrano et al. [132] produced Ag NPs through an eco-friendly approach using soil fungal to treat UPEC UTIs. Escherichia coli tend to form a biofilm which reduces the penetration and the efficacy of conventional antibiotics. The biogenic Ag NPs were formulated using metabolites excreted from the fungal strains. The prepared formulations had a minimum inhibitory concentration (MIC) of $7.5 \mathrm{mg} / \mathrm{mL}$ with a $97 \%$ reduction in biofilm formation and an $80 \%$ destruction of the matured biofilm, while the control group had a MIC value of $25 \mathrm{mg} / \mathrm{mL}$.

Foley catheters are essential in the healthcare unit and pathogens tend to form biofilms on the surface of catheters, leading toward UTIs. To prevent this problem, researchers functionalized the surface of catheters using a combination of Ag NPs and antibiotics [133]. NPs were produced in a size range of $42-75 \mathrm{~nm}$ for investigation in vivo in mice. The combination of amikacin, nitrofurantoin, and Ag NPs exhibited synergistic activity. Mice treated with the combination approach did not show any kind of colonization until day 14 . After 2 years, the catheters treated with antibiotics exhibited a $25 \%$ reduction in bacterial adhesion while the group treated with Ag NPs along with antibiotics displayed a $90 \%$ 
decline in bacteria adhesion. Shafreen et al. [134] also formulated Ag NPs using fresh water diatom, showing inhibition against Escherichia coli at a concentration of $300 \mathrm{ng} / \mathrm{mL}$ and decreasing biofilm formation. Confocal laser microscopy further showed that the architecture of the biofilm was also significantly decreased. Valsalam et al. [135] prepared $\mathrm{Ag}$ NPs through an eco-friendly approach using leaf extract from Tropaeolum majus. Both Ag NPs and plant extract inhibited Pseudomonas aeroginosa at a concentration of $6.25 \mu \mathrm{g} / \mathrm{mL}$ relative to other microbial strains and exhibited antifungal and anticancer activities that may be used for the treatment of other infectious diseases.

\subsection{Copper NPs}

Due to the redox-active properties of copper, several groups employed copper-based NPs for their activity against UTIs. In this regard, Al-Enizi et al. [136] formulated a copper NP-based hydrogel matrix, with a particle size distribution of 7-12 nm. The antimicrobial and cytotoxic activities of the formulation were evaluated in UTI microbes (Escherichia coli, Klebsiella pnemoniae, Pseudomonas aeruginosa, Proteus vulgaris, Staphylococcus aureus, Proteus mirabilis) and HeLa cell lines. Compared with a simple gel matrix, the copper NP-based hydrogel matrix exhibited a significantly higher zone of inhibition against UTI pathogens while cytotoxicity studies revealed the suitability of the prepared carrier system for biomedical applications. Shalom et al. [137] fabricated zinc-doped copper oxide NPs for the treatment of catheter-linked UTIs. The NPs were deposited on the surface of the catheter through the sonochemical technique. The surface-coated catheter exhibited higher antibiofilm property, biocompatibility, reduced cytokines secretion, lower cytotoxicity, and absence of irritation in rabbits. The coated catheters did not produce UTIs even 7 days after application while the uncoated catheters exhibited UTIs within 4 days.

\subsection{Silicone Dioxide-Based NPS}

Muslim et al. [138] generated tannase-conjugated silicone dioxide-based NPs through laser ablation technique, noting higher therapeutic effectiveness and significance levels against all UTI pathogenic strains compared with control groups, as an effective approach against UTIs.

\subsection{Zinc Oxide NPs}

Zinc oxide NPs exhibit cell internalization and bactericidal effects against several microbial strains involved in UTIs. Due to these properties, several researchers used zinc oxide (ZnO)-based NPs for therapy against UTIs.

In this context, Santhoshkumar et al. [139] fabricated Passiflora caerulea leaf extractbased $\mathrm{ZnO}$ NPs. Compared with simple leaf extract, the leaf extract-laden ZnO NPs exhibited a significantly higher zone of inhibition in the pathogenic microbes extracted from patients' urine containing UTIs. Abd Elkodous et al. [140] examined the antimicrobial and antibiofilm properties of ZnO NPs against MDR bacterial strains involved in UTIs. The NPs exhibited a particle size of $69 \mathrm{~nm}$, a surface area of $10.66 \mathrm{~m}^{2} / \mathrm{g}$, and porosity of $13.16 \%$ and displayed antimicrobial and antibiofilm activities against all the pathogenic UTI strains. Tiwari et al. [141] investigated the potential of ZnO NPs against carbapenem-resistant microbial strains. The NPs were $30 \mathrm{~nm}$ in size and displayed significant antibacterial activities against the resistant strains. The authors also investigated the mechanisms of microbial inhibition and found that ZnO NPs promoted the production of ROS which, in turn, increased the peroxidation of the bacterial membrane lipids and the leakage of DNA, reducing sugars, proteins, and ultimately leading to a reduction of the cell viability. These results demonstrated that ZnO NPs have the potential to be effectively used against the resistant strains of UTIs. Similarly, El-Rab et al. [142] evaluated the inhibition potential and mechanism of ZnO NPs against the MDR strains of Escherichia coli and Escherichia hermannii. The NPs inhibited Escherichia coli at a concentration of $10 \mu \mathrm{g} / \mathrm{mL}$ and Escherichia hermannii at $40 \mu \mathrm{g} / \mathrm{mL}$. The MIC values reported in the study were also significantly lower than in earlier evaluations. The authors also evaluated the mechanisms of inhibition of the microbes 
and an SEM analysis showed the distortion and blebbing of the microbial membrane, with an elongation of the cell membrane and a discharge of cellular contents. In another study, Hosseini et al. [143] tested the impact of ZnO NPs on the initiation, adhesion, agglutinin sequence, and gene expression in biofilm formation. The NPs displayed size of $20-40 \mathrm{~nm}$ and MIC in the range of $0.02-18.1 \mu \mathrm{g} / \mathrm{mL}$. The authors observed that at this concentration, the NPs induced an initial inhibition and then tremendous reduction of the expression of genes responsible for biofilm formation. Such NPs may thus be effectively used to prevent biofilm formation with increased efficacy against microbes. Hosseini et al. [144] evaluated the impact of ZnO NPs on the adhesion of Candida albicans on surface catheter and biofilm formation. Among the several bacterial species tested, Candida albicans fluconazole-resistant strains exhibited higher adherence to the surface of catheters. The surface-adhered catheters were then treated with $\mathrm{ZnO} N P s$, leading to a reduced biofilm mass. This study illustrated that ZnO NPs may be additionally used for the treatment of catheter-allied UTIs.

\subsection{Selenium-Based NPs}

El-Sayyad et al. [145] formulated gentamicin-laden selenium NPs to compare and increase the antibiofilm and antimicrobial activities of conventional gentamicin formulations against MDR microbial strains. The NPs had a particle size distribution in the range of $22-33 \mathrm{~nm}$ and displayed antimicrobial properties against all MDR strains of UTIs. The formulation also showed enhanced antibiofilm properties of $88 \%$ against Staphylococcus aureus, $87 \%$ against $P$ seudomonas aeruginosa, and 85\% against Escherichia coli.

\subsection{Sulfur-Based NPS}

The majority of microbial strains exhibit resistance to trimethoprim and amoxicillin. To overcome such resistance, Paralikar et al. [146] prepared sulfur NPs (SNPs) loaded with trimethoprim and amoxicillin with a size in the range of $20-86 \mathrm{~nm}$ and with lower polydispersity index. SNPs combined with trimethoprim and amoxicillin exerted a synergistic effect and higher zone of inhibition against the resistant microbial strains compared with unloaded SNPs.

\subsection{Polymeric NPs}

Due to their high stability, encapsulation efficiency, and ability to modify the surface properties, polymeric NPs are extensively utilized as a nanocarrier for the efficient loading of antimicrobial agents. To exploit such properties, Park et al. [147] generated a pHsensitive and redox-responsive polymer-based nanocarrier for the efficient delivery of amphotericin B. The authors further attached the functional moieties with an antifungal histatin 5 peptide allowing for targeted delivery and displaying antifungal properties against Candida albicans. The mechanisms of targeted delivery are presented in Figure 3. Compared with free amphotericin B, the nanoformulation exhibited higher therapeutic efficacy and targeted delivery to the pathogenic microbe-laden cells at lower doses while reducing the cytotoxicity to healthy cells.

Crystalline deposition and formation of biofilms are the common reasons for the failure of prolonged urinary catheter-based therapy against UTIs. Bacteria colonize the surface of the catheter, block it, ultimately leading to serious UTIs. To address this problem, Dayyoub et al. [148] developed a new strategy to counteract the adhesion of pathogens to the catheter surface based on a nanoformulation consisting of norfloxacin, Ag NPs, and polylactic-co-glycolic acid (PLGA)-based polymers which underwent degradation in the aqueous environment and produced alkali products through the hydrolysis of the urea. The authors examined the adhesion of the NPs embedded with tetraether lipids on silicone and polyurethane sheets. Compared with commercial formulations, the current NPs exhibited significantly higher anti-adhesion and antimicrobial properties. An in vivo encrustation model revealed that the lipid coating reduced adhesion for 2 weeks, supporting the concept of using such a system as an efficient coating for urinary catheters. 
A

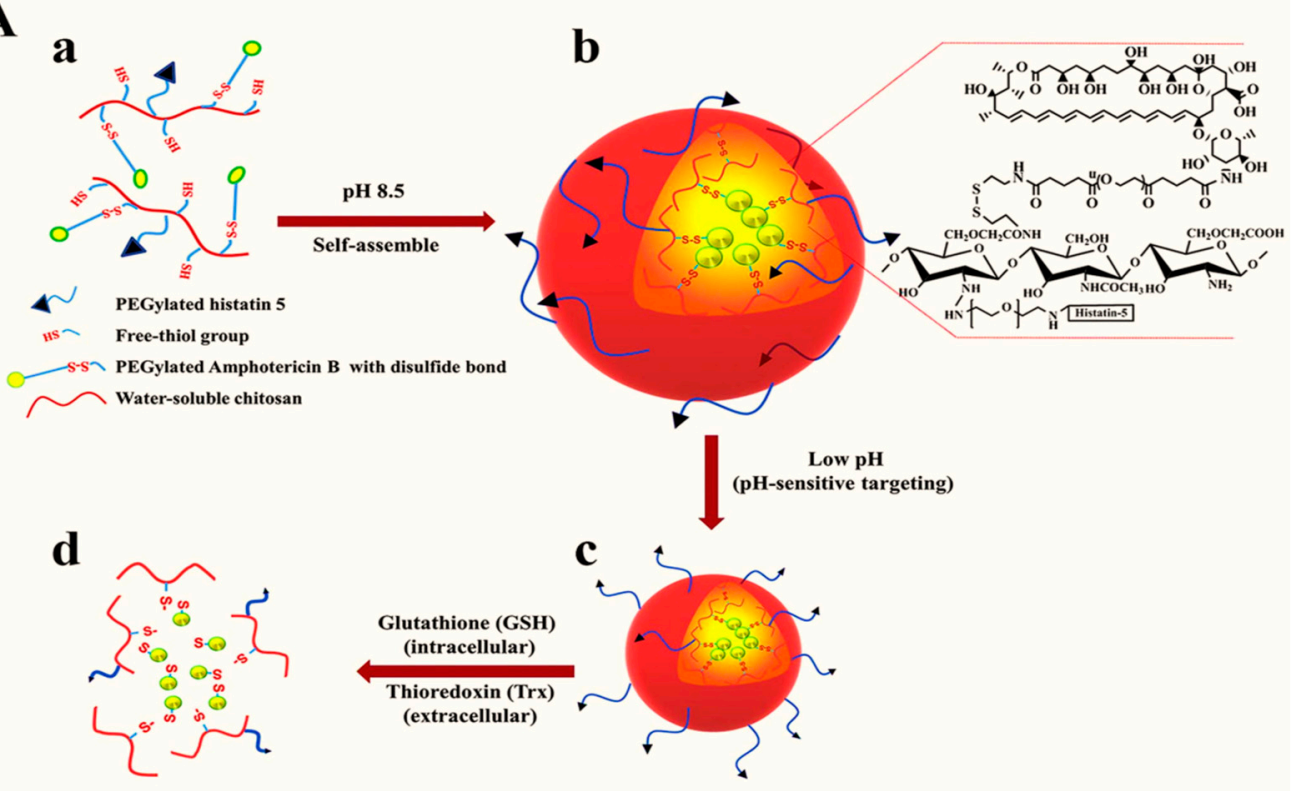

B

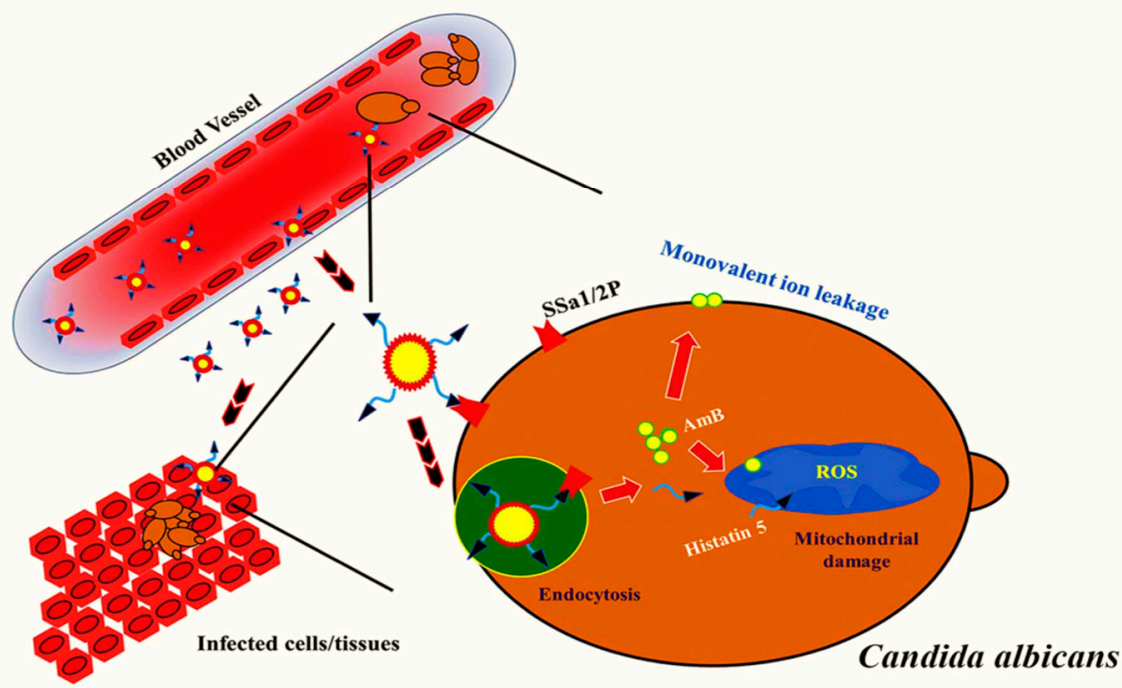

Figure 3. Conjugation of histatin 5 and amphotericin B with NPs. (A) conjugation of histatin 5 with chitosan and conjugation of a redox linker with amphotericin B (a), self-assembly of NPs through disulfide bonds between polymeric chains and formation of micelles through hydrophobic interaction of amphotericin B (b), pH-dependent activation of the targeting ligand, i.e., histatin 5 (c), release of amphotericin B through a reduction mechanism within the fungal cell (d). (B) Targeted uptake and intraendosomal release of amphotericin B and synergistic action of histatin B against fungal destruction. Reproduced from [147], with permission from Elsevier, 2021.

Intravesical therapy used for therapy against bladder cancer may be further adapted for the treatment of UTIs, although certain issues associated with this technique still need attention such as a short dwelling and washout period. In this regard, Brauner et al. [149] formulated two types of PLGA 2300- and PLGA 503H-based NP surface tailored with wheat germ agglutinin. Both types of NPs significantly enhanced the adhesion of the NPs to human uroepithelial cells while the loading of trimethoprim did not alter the adhesion potential of the NPs. The highest adhesion was observed in sodium bicarbonate buffer at $\mathrm{pH}$ 5. The dwelling time was in the range of $15-30 \mathrm{~min}$, and after $15 \mathrm{~min}$ less than $50 \%$ of the NPs were bound to the surface while more than $70 \%$ were bound after 30 min, without further increment beyond this time point. Such surface-functionalized NPs may thus be used as a promising approach for therapy against UTIs. 
Amphotericin B is a commonly used antibiotic for UTIs, yet it may lead to hemolytic anemia and nephrotoxicity. In an attempt to reduce such hurdles, Ludwig et al. [150] created PLGA-based NPs decorated with chitosan for the efficient loading of amphotericin B. The NPs exhibited a size of $460 \mathrm{~nm}$ and encapsulation efficiency of $46 \%$. Compared with free drugs, amphotericin B-loaded NPs exhibited lower MIC, a higher zone of inhibition, and reduced adverse effects.

Sharma et al. [151] developed chitosan-based zingerone NPs against Pseudomonas aeruginosa to treat catheter-induced UTIs. Due to the antimicrobial properties of chitosan, these NPs exhibited a synergistic effect against the pathogens without toxicity in kidney cell lines. Findings in vivo revealed that chitosan-based NPs decreased the bacterial cell count in the bladder and renal tissues and ex vivo studies evidence the intracellular killing of the pathogen and higher uptake by phagocytes with an important reduction of the level of several inflammatory mediators.

\subsection{Hybrid NPs (Polymeric/Metallic NPs)}

One of the reasons for the occurrence of UTIs is the presence of the ureteral stent and the pain associated with extraction. In this regard, Gao et al. [152] prepared an extraction of free, biodegradable, and antibacterial stent having a continuous renewable surface and antibiofilm properties through the construction of poly(amide-amine)-capped Ag shell and Au core nanoparticle (Ag@Au NP)-embedded fiber membrane-structured poly(glycolic acid) (PGA)/PGLA NPs. The stent exhibited a rapid killing kinetics of Staphylococcus aureus and Escherichia coli within 10 and $5 \mathrm{~min}$, respectively, along with an inhibition rate of up to $99 \%$. The gradual degradation of PGA and PLGA self-cleaned the stent and also displayed antibacterial properties through constant exfoliation of the surface of the stent. The stent also exhibited biocompatibility, lower cytotoxicity, and bactericidal activity. In vivo studies in pigs revealed that the stent had significant antibiofilm properties and decreased the levels of necrotic and inflammatory cells, as a promising and extraction-free approach to treat UTIs.

Ashmore et al. [111] compared the antimicrobial properties of polymer-coated Ag NPs, i.e., $10 \% \mathrm{Ag}(\mathrm{Ag} 10 \%+$ polymer) and $99 \% \mathrm{Ag}$ (Ag-polyvinylpyrrolidone-AgPVP), versus uncoated NPs. NPs coated with polymer exhibited higher potency against Escherichia coli compared with the uncoated NPs, with bacterial growth inhibited within $8 \mathrm{~h}$ at a concentration of $0.156 \mathrm{mg} / \mathrm{mL}$ while uncoated NPs were effective at $0.312 \mathrm{mg} / \mathrm{mL}$. An SEM analysis revealed that the formulations destroyed the cell membrane, leading to bacterial cell rupture and expulsion of the cellular content.

Acinetobacter baumannii is one of the several microbes with MDR against UTIs, with all conventional antibiotics being largely ineffective to prevent their occurrence. Plant-based extracts have currently gained much attention to avoid the problem of MDR. With this in mind, Tiwari et al. [153] investigated plant extracts from various species to explore their antimicrobial activities against MDR pathogenic microbes. Among them, a complete extract or primary and secondary metabolites from Phyllanthus emblica showed the highest inhibition potential for carbapenem-resistant Acinetobacter baumannii via the production of ROS, carbonylation of proteins, and membrane damage. To further confirm the antimicrobial properties of the secondary metabolites, gallate (the major secondary metabolite of the plant)-laden PVP-capped hybrid Ag NPs (G-PVP-Ag NPs) were formulated and had significant antimicrobial activity also via ROS production.

\subsection{Surfactant-Based NPs}

Pseudomonas aeruginosa is the microorganism that causes hospital-acquired UTIs. This organism can grow in a free form as well as on biofilm colonies attached to a surface. When the species grows in the biofilms, the presence of biofilms limits the efficacy of conventional formulations, leading to its resistance. To overcome this issue, Lopes et al. [154] evaluated the anti-biofilm potential of a glycerol monolaurate (GML) nanoformulation with an average diameter of $190 \mathrm{~nm}$. Compared with free GML, GML nanocapsules reduced the 
MIC from 62.5 to $15.62 \mu \mathrm{g} / \mathrm{mL}$ as well as the biofilm mass, polysaccharides, proteins, and the presence of Pseudomonas aeruginosa on the biofilms.

\subsection{Carbon-Based Nanomaterials}

Carbon-based nanomaterials have been widely employed due to their unique optical and tunable surface properties, low systemic toxicities, cost-effectiveness, and antimicrobial activities. Due to these features, Lu et al. [155] took advantage of carbonbased materials against UTIs, such as graphene, carbon nanotubes, and nanodiamonds. Dybowska-Sarapuk et al. [156] also formulated carbon-based nanolayers using graphene decorated with Ag NPs against the formation of Staphylococcus epidermidis-induced biofilm on the surface of the Foley catheter. Such graphene-nanoAg nanolayers were capable of preventing biofilm formation on the surface of the catheter, as a strong tool against the complications associated with UTIs. Rouhani et al. [157] functionalized amoxicillin-based nanodiamonds with polyethyleneimine (PEI) and conjugation with ferromagnetic material $\left(\mathrm{Fe}_{3} \mathrm{O}_{4}\right)$ to achieve active targeted delivery. The nanodiamonds were capable to release the drug in the target sites to overcome the problem of dose-related resistance associated with a free drug approach against UTIs.

It is estimated that there are $25-45 \%$ chances of relapse in women suffering from UTIs mostly due to Escherichia coli infection, as a result of the internalization of the pathogen in the urinary bladder and since antibiotics fail to reach the target site. To tackle this problem, Iyer et al. [158] prepared two types of nanodiamonds with sizes of 6 and $25 \mathrm{~nm}$ to kill intracellular and extracellular pathogens. Nanodiamonds with a size of $6 \mathrm{~nm}$ had a more potent internalization capability than $25 \mathrm{~nm}$-sized systems, using a mechanism based on actin-dependent endocytosis, and better reduced bacterial infiltration, improving the killing kinetics of the Escherichia coli.

\subsection{Dendrimer-Based Nanomaterials}

Dendrimers are artificial macromolecules with several functional groups and an intact molecular structure, playing an increasing role in drug delivery via the fabrication of nanoscale particles. Sehad et al. [159] created surface-functionalized dendrimers by attaching mannose sugar on the surface of the dendrimers through copper-catalyzed cycloaddition click reaction. The mannosylated dendrimers were constructed to examine the impact of mannosylation upon the binding capacity of dendrimers on the bacterial cell surface. The dendrimers had the ability to bind with FimH type-1 lectins present at the tip of bacterial fimbriae, showing high potency, bioadhesion, and antibiofilm properties against Escherichia coli. Zhu et al. [160] generated mannoside-decorated dendrimers to increase the formation of a protecting coating to avoid the adhesion of pathogenic microbes at the surface of silicone catheters. The authors reported that $95 \%$ of nonpathogenic microbes were retained on the catheters while all MDR pathogenic strains were excluded from colonization at their surface. The most commonly used nanoparticle-based delivery approaches against several species of UTIs are presented in Table 2. 
Table 2. Most commonly used NP-based delivery approaches for therapy against UTIs.

\begin{tabular}{|c|c|c|c|c|}
\hline \multicolumn{2}{|c|}{ NPs } & Pathogens & Properties & References \\
\hline \multirow{3}{*}{$\begin{array}{l}\text { metallic } \\
\text { NPs }\end{array}$} & $\mathrm{Ag}$ & Escherichia coli & $\begin{array}{c}\text { MIC of } 7.5 \mathrm{mg} / \mathrm{mL}, 97 \% \text { reduction of } \\
\text { biofilm formation, } 80 \% \text { destruction of } \\
\text { matured biofilms }\end{array}$ & [132] \\
\hline & Copper & $\begin{array}{l}\text { Escherichia coli, Klebsiella pnemoniae, } \\
\text { Pseudomonas aeruginosa, Proteus vulgaris, } \\
\text { Staphylococcus aureus, Proteus mirabilis }\end{array}$ & $\begin{array}{l}\text { high zone of inhibition against UTI } \\
\text { pathogens, low cytotoxicity of the NPs }\end{array}$ & [161] \\
\hline & $\mathrm{ZnO}$ & Escherichia coli, Escherichia hermannii & $\begin{array}{c}\text { anti-bacterial effects at } 10 \text { and } 40 \mu \mathrm{g} / \mathrm{mL} \\
\text { (Escherichia coli, Escherichia hermannii), } \\
\text { low MIC }\end{array}$ & [162] \\
\hline \multicolumn{2}{|c|}{$\begin{array}{c}\text { polymeric NPs } \\
\text { (chitosan-based NPs) }\end{array}$} & Candida albicans & $\begin{array}{l}\text { high therapeutic efficacy and targeting } \\
\text { of pathogenic microbe-laden cells, } \\
\text { low cytotoxicity }\end{array}$ & [163] \\
\hline \multicolumn{2}{|c|}{ hybrid NPs } & Escherichia coli & $\begin{array}{l}\text { high potency (inhibition of bacterial } \\
\text { growth within } 8 \mathrm{~h} \text { at } 0.156 \mathrm{mg} / \mathrm{mL} \text { ) }\end{array}$ & [111] \\
\hline \multicolumn{2}{|c|}{ carbon-based NPs } & Staphylococcus epidermidis & $\begin{array}{l}\text { prevention of biofilm formation on } \\
\text { Foley catheter by graphene-nano } \\
\text { Ag nanolayers }\end{array}$ & [164] \\
\hline
\end{tabular}

Abbreviations: NPs, nanoparticles; Ag, silver; ZnO, zinc oxide; MIC, minimum inhibitory concentration; UTI, urinary tract infection.

\section{Conclusions, Challenges, and Perspectives}

Compared with conventional therapies, NP-mediated delivery of antimicrobials displays higher therapeutic efficacy by minimizing off-target delivery and by managing MDR. The issue of biofilm formation, an additional barrier that impairs the therapeutic efficacy of antimicrobials, may also be addressed using the nanotechnology procedure, especially when using metallic NPs that possess an intrinsic antibiofilm formation potential. With the emerging role of nanotechnology in drug delivery and diagnostics, this approach may further overcome the limitations of conventional therapies in clinical trials, making it the most appealing strategy for the diagnosis, treatment, and prevention of UTIs. In order to minimize the seriousness of these infections, the early diagnosis of UTIs will play a major role in their rapid eradication, and any delay in effective UTI detection may result in the development of intracellular reservoirs particularly difficult to eliminate. The integration of nanomaterials with the currently available diagnosis methods will be a strong option for the early-stage identification of UTIs and may solve the major constraints in evaluation and therapy, including infection recurrence. Although NPs have the potential to treat and diagnose UTIs, there are still several challenges that need to be addressed prior to their successful translation in the clinics including the investigation of the interaction between NPs and cells, tissues, and organs, the identification of the most appropriate routes of administration, and most importantly the evaluation of toxic responses to long-term exposure to NPs. Despite several advancements regarding the value of NPs in the diagnosis and treatment of UTIs, it will be important to examine the pathways through which NPs exert their therapeutic efficacy. There is also limited information on the metabolism and clearance of NPs and on the nature of their targets. The specific combination of NPs and antimicrobials may reduce the emergence of multidrug resistance of bacteria to drug sensitivity and translation to clinical practice will require a thorough investigation of the pharmacokinetic and pharmacodynamic profiles of these NPs. Finally, for innovative research, the limits of pathogen detection and the time of the proposed analysis will have to be significantly improved.

Author Contributions: Conceptualization, A.R.; writing-original draft preparation, M.Q., M.B., A.R., R.A.; writing-review and editing, A.R., M.C. All authors have read and agreed to the published version of the manuscript. 
Funding: This work was supported by the Saarland University within the funding programme Open Access Publishing.

Institutional Review Board Statement: Not applicable.

Informed Consent Statement: Not applicable.

Data Availability Statement: Not applicable.

Conflicts of Interest: The authors declare no conflict of interest.

\section{References}

1. Öztürk, R.; Murt, A. Epidemiology of urological infections: A global burden. World J. Urol. 2020, 38, 2669-2679. [CrossRef]

2. Stern, J.H.; Rutkowski, J.M.; Scherer, P.E. Adiponectin, leptin, and fatty acids in the maintenance of metabolic homeostasis through adipose tissue crosstalk. Cell Metab. 2016, 23, 770-784. [CrossRef]

3. Kim, Y.J.; Tae, B.S.; Bae, J.H. Cognitive function and urologic medications for lower urinary tract symptoms. Int. Neurourol. J. 2020, 24, 231. [CrossRef]

4. Klein, R.D.; Hultgren, S.J. Urinary tract infections: Microbial pathogenesis, host-pathogen interactions and new treatment strategies. Nat. Rev. Microbiol. 2020, 18, 211-226. [CrossRef]

5. Washino, S.; Hosohata, K.; Miyagawa, T. Roles played by biomarkers of kidney injury in patients with upper urinary tract obstruction. Int. J. Mol. Sci. 2020, 21, 5490. [CrossRef]

6. $\quad$ Eckert, L.; Mattia, L.; Patel, S.; Okumura, R.; Reynolds, P.; Stuiver, I. Reducing the risk of indwelling catheter-associated urinary tract infection in female patients by implementing an alternative female external urinary collection device: A quality improvement project. J. Wound Ostomy Cont. Nurs. 2020, 47, 50-53. [CrossRef] [PubMed]

7. Toosky, M.N.; Grunwald, J.T.; Pala, D.; Shen, B.; Zhao, W.; D’Agostini, C.; Coghe, F.; Angioni, G.; Motolese, G.; Abram, T.J. A rapid, point-of-care antibiotic susceptibility test for urinary tract infections. J. Med. Microbiol. 2020, 69, 52-62. [PubMed]

8. Wagenlehner, F.M.; Johansen, T.E.B.; Cai, T.; Koves, B.; Kranz, J.; Pilatz, A.; Tandogdu, Z. Epidemiology, definition and treatment of complicated urinary tract infections. Nat. Rev. Urol. 2020, 17, 586-600. [CrossRef]

9. Barchitta, M.; Maugeri, A.; Favara, G.; Riela, P.M.; La Mastra, C.; La Rosa, M.C.; San Lio, R.M.; Gallo, G.; Mura, I.; Agodi, A. Cluster analysis identifies patients at risk of catheter-associated urinary tract infections in intensive care units: Findings from the SPIN-UTI Network. J. Hosp. Infect. 2020, 107, 57-63. [CrossRef]

10. Almalki, M.A.; Varghese, R. Prevalence of catheter associated biofilm producing bacteria and their antibiotic sensitivity pattern. $J$. King Saud Univ. Sci. 2020, 32, 1427-1433. [CrossRef]

11. Carey, M.R.; Vaughn, V.M.; Mann, J.; Townsend, W.; Chopra, V.; Patel, P.K. Is non-steroidal anti-inflammatory therapy non-inferior to antibiotic therapy in uncomplicated urinary tract infections: A systematic review. J. Gen. Intern. Med. 2020, 35, 1821-1829. [CrossRef] [PubMed]

12. Alidjanov, J.F.; Naber, K.G.; Pilatz, A.; Radzhabov, A.; Zamuddinov, M.; Magyar, A.; Tenke, P.; Wagenlehner, F.M. Evaluation of the draft guidelines proposed by EMA and FDA for the clinical diagnosis of acute uncomplicated cystitis in women. World J. Urol. 2020, 38, 63-72. [CrossRef]

13. Daneman, N.; Château, D.; Dahl, M.; Zhang, J.; Fisher, A.; Sketris, I.; Quail, J.; Marra, F.; Ernst, P.; Bugden, S. Fluoroquinolone use for uncomplicated urinary tract infections in women: A retrospective cohort study. Clin. Microbiol. Infect. 2020, 26, 613-618. [CrossRef]

14. Behzadi, P.; Urbán, E.; Matuz, M.; Benkő, R.; Gajdács, M. The role of gram-negative bacteria in urinary tract infections: Current concepts and therapeutic options. Adv. Exp. Med. Biol. 2020. [CrossRef]

15. Gajdács, M.; Ábrók, M.; Lázár, A.; Burián, K. Increasing relevance of Gram-positive cocci in urinary tract infections: A 10-year analysis of their prevalence and resistance trends. Sci. Rep. 2020, 10, 1-11. [CrossRef]

16. Bassetti, M.; Echols, R.; Matsunaga, Y.; Ariyasu, M.; Doi, Y.; Ferrer, R.; Lodise, T.P.; Naas, T.; Niki, Y.; Paterson, D.L. Efficacy and safety of cefiderocol or best available therapy for the treatment of serious infections caused by carbapenem-resistant Gramnegative bacteria (CREDIBLE-CR): A randomised, open-label, multicentre, pathogen-focused, descriptive, phase 3 trial. Lancet Infect. Dis. 2021, 21, 226-240. [CrossRef]

17. Hozzari, A.; Behzadi, P.; Khiabani, P.K.; Sholeh, M.; Sabokroo, N. Clinical cases, drug resistance, and virulence genes profiling in uropathogenic Escherichia coli. J. Appl. Genet. 2020, 61, 265-273. [CrossRef] [PubMed]

18. Behzadi, P. Classical chaperone-usher (CU) adhesive fimbriome: Uropathogenic Escherichia coli (UPEC) and urinary tract infections (UTIs). Folia Microbiol. 2020, 65, 45-65. [CrossRef]

19. Wasfi, R.; Hamed, S.M.; Abd Allah, M.A.W.; Ismail, L. Proteus mirabilis biofilm: Development and therapeutic strategies. Front. Cell. Infect. Microbiol. 2020, 10, 414. [CrossRef] [PubMed]

20. Vagios, S.; Hesham, H.; Mitchell, C. Understanding the potential of lactobacilli in recurrent UTI prevention. Microb. Pathog. 2020, 148, 104544. [CrossRef]

21. Heidemann, J.; Schmitz, B.; Kostev, K. Association between antiseizure medication use and risk of urinary tract infection: A case-control study. Epilepsy Behav. 2020, 115, 107502. [CrossRef] [PubMed] 
22. Zhong, Z.-X.; Cui, Z.-H.; Li, X.-J.; Tang, T.; Zheng, Z.-J.; Ni, W.-N.; Fang, L.-X.; Zhou, Y.-F.; Yu, Y.; Liu, Y.-H. Nitrofurantoin combined with amikacin: A promising alternative strategy for combating MDR uropathogenic Escherichia coli. Front. Cell. Infect. Microbiol. 2020, 10, 811. [CrossRef] [PubMed]

23. Loubet, P.; Ranfaing, J.; Dinh, A.; Dunyach-Remy, C.; Bernard, L.; Bruyère, F.; Lavigne, J.-P.; Sotto, A. Alternative therapeutic options to antibiotics for the treatment of urinary tract infections. Front. Microbiol. 2020, 11, 1509. [CrossRef] [PubMed]

24. Magistro, G.; Stief, C.G. Vaccine development for urinary tract infections: Where do we stand? Eur. Urol. Focus 2019, 5, 39-41. [CrossRef] [PubMed]

25. AL-Khikani, F.H.O.; Abadi, R.M.; Ayit, A.S. Emerging carbapenemase Klebsiella oxytoca with multidrug resistance implicated in urinary tract infection. Biomed. Biotechnol. Res. J. (BBRJ) 2020, 4, 148.

26. Horváth, J.; Wullt, B.; Naber, K.G.; Köves, B. Biomarkers in urinary tract infections-Which ones are suitable for diagnostics and follow-up? GMS Infect. Dis. 2020. [CrossRef]

27. Martínez-Figueroa, C.; Cortés-Sarabia, K.; del Carmen Alarcón-Romero, L.; Catalán-Nájera, H.G.; Martínez-Alarcón, M.; VencesVelázquez, A. Observation of intracellular bacterial communities in urinary sediment using brightfield microscopy; a case report. BMC Urol. 2020, 20, 89. [CrossRef]

28. Dospinescu, V.-M.; Tiele, A.; Covington, J.A. Sniffing out urinary tract infection-Diagnosis based on volatile organic compounds and smell profile. Biosensors 2020, 10, 83. [CrossRef]

29. Dixon, M.; Stefil, M.; McDonald, M.; Bjerklund-Johansen, T.E.; Naber, K.; Wagenlehner, F.; Mouraviev, V. Metagenomics in diagnosis and improved targeted treatment of UTI. World J. Urol. 2020, 38, 35-43. [CrossRef]

30. Fritzenwanker, M.; Imirzalioglu, C.; Chakraborty, T.; Wagenlehner, F.M. Modern diagnostic methods for urinary tract infections. Expert Rev. Anti-Infect. Ther. 2016, 14, 1047-1063. [CrossRef]

31. Thapaliya, J.; Khadka, P.; Thapa, S.; Gongal, C. Enhanced quantitative urine culture technique, a slight modification, in detecting under-diagnosed pediatric urinary tract infection. BMC Res. Notes 2020, 13, 5. [CrossRef]

32. Bannov, A.G.; Popov, M.V.; Kurmashov, P.B. Thermal analysis of carbon nanomaterials: Advantages and problems of interpretation. J. Therm. Anal. Calorim. 2020, 142, 349-370. [CrossRef]

33. Kumar, M.S.; Das, A.P. Emerging nanotechnology based strategies for diagnosis and therapeutics of urinary tract infections: A review. Adv. Colloid Interface Sci. 2017, 249, 53-65. [CrossRef] [PubMed]

34. Bartelds, R.; Nematollahi, M.H.; Pols, T.; Stuart, M.C.; Pardakhty, A.; Asadikaram, G.; Poolman, B. Niosomes, an alternative for liposomal delivery. PLoS ONE 2018, 13, e0194179. [CrossRef] [PubMed]

35. Nematollahi, M.H.; Pardakhty, A.; Torkzadeh-Mahanai, M.; Mehrabani, M.; Asadikaram, G. Changes in physical and chemical properties of niosome membrane induced by cholesterol: A promising approach for niosome bilayer intervention. RSC Adv. 2017, 7, 49463-49472. [CrossRef]

36. Goudarzi, K.A.; Nematollahi, M.H.; Khanbabaei, H.; Nave, H.H.; Mirzaei, H.R.; Pourghadamyari, H.; Sahebkar, A. Targeted delivery of CRISPR/Cas13 as a promising therapeutic approach to treat SARS-CoV-2. Curr. Pharm. Biotechnol. 2020. [CrossRef]

37. Dakal, T.C.; Kumar, A.; Majumdar, R.S.; Yadav, V. Mechanistic basis of antimicrobial actions of silver nanoparticles. Front. Microbiol. 2016, 7, 1831. [CrossRef] [PubMed]

38. Kumar, H.; Bhardwaj, K.; Dhanjal, D.S.; Nepovimova, E.; Sen, F.; Regassa, H.; Singh, R.; Verma, R.; Kumar, V.; Kumar, D. Fruit extract mediated green synthesis of metallic nanoparticles: A new avenue in pomology applications. Int. J. Mol. Sci. 2020, 21, 8458. [CrossRef] [PubMed]

39. Ghazy, E.; Kumar, A.; Barani, M.; Kaur, I.; Rahdar, A.; Behl, T. Scrutinizing the therapeutic and diagnostic potential of nanotechnology in thyroid cancer: Edifying drug targeting by nano-oncotherapeutics. J. Drug Deliv. Sci. Technol. 2021, 61, 102221. [CrossRef]

40. Ghazy, E.; Rahdar, A.; Barani, M.; Kyzas, G.Z. Nanomaterials for Parkinson disease: Recent progress. J. Mol. Struct. 2020, 129698. [CrossRef]

41. Hajizadeh, M.R.; Maleki, H.; Barani, M.; Fahmidehkar, M.A.; Mahmoodi, M.; Torkzadeh-Mahani, M. In vitro cytotoxicity assay of D-limonene niosomes: An efficient nano-carrier for enhancing solubility of plant-extracted agents. Res. Pharm. Sci. 2019, 14, 448. [PubMed]

42. Hasanein, P.; Rahdar, A.; Barani, M.; Baino, F.; Yari, S. Oil-in-water microemulsion encapsulation of antagonist drugs prevents renal ischemia-reperfusion injury in rats. Appl. Sci. 2021, 11, 1264. [CrossRef]

43. Mukhtar, M.; Bilal, M.; Rahdar, A.; Barani, M.; Arshad, R.; Behl, T.; Brisc, C.; Banica, F.; Bungau, S. Nanomaterials for diagnosis and treatment of brain cancer: Recent updates. Chemosensors 2020, 8, 117. [CrossRef]

44. Nikazar, S.; Barani, M.; Rahdar, A.; Zoghi, M.; Kyzas, G.Z. Photo- and magnetothermally responsive nanomaterials for therapy, controlled drug delivery and imaging applications. ChemistrySelect 2020, 5, 12590-12609. [CrossRef]

45. Abdal Dayem, A.; Hossain, M.K.; Lee, S.B.; Kim, K.; Saha, S.K.; Yang, G.-M.; Choi, H.Y.; Cho, S.-G. The role of reactive oxygen species (ROS) in the biological activities of metallic nanoparticles. Int. J. Mol. Sci. 2017, 18, 120. [CrossRef]

46. Singh, J.; Dutta, T.; Kim, K.-H.; Rawat, M.; Samddar, P.; Kumar, P. 'Green' synthesis of metals and their oxide nanoparticles: Applications for environmental remediation. J. Nanobiotechnol. 2018, 16, 84. [CrossRef]

47. Arshad, R.; Sohail, M.F.; Sarwar, H.S.; Saeed, H.; Ali, I.; Akhtar, S.; Hussain, S.Z.; Afzal, I.; Jahan, S.; Shahnaz, G. ZnO-NPs embedded biodegradable thiolated bandage for postoperative surgical site infection: In vitro and in vivo evaluation. PLoS ONE 2019, 14, e0217079. [CrossRef] [PubMed] 
48. Gour, A.; Jain, N.K. Advances in green synthesis of nanoparticles. Artif. Cells Nanomed. Biotechnol. 2019, 47, 844-851. [CrossRef]

49. Bayat, M.; Chudinova, E.; Zargar, M.; Lyashko, M.; Louis, K.; Adenew, F.K. Phytoassisted green synthesis of zinc oxide nanoparticles and its antibacterial and antifungal activity. Res. Crop. 2019, 20, 725-730.

50. Kamran, U.; Bhatti, H.N.; Iqbal, M.; Nazir, A. Green synthesis of metal nanoparticles and their applications in different fields: A review. Z. Phys. Chem. 2019, 233, 1325-1349. [CrossRef]

51. Akbarzadeh, F.; Motaghi, M.; Chauhan, N.P.S.; Sargazi, G. A novel synthesis of new antibacterial nanostructures based on Zn-MOF compound: Design, characterization and a high performance application. Heliyon 2020, 6, e03231. [CrossRef] [PubMed]

52. Sargazi, G.; Afzali, D.; Mostafavi, A.; Shadman, A.; Rezaee, B.; Zarrintaj, P.; Saeb, M.R.; Ramakrishna, S.; Mozafari, M. Chitosan/polyvinyl alcohol nanofibrous membranes: Towards green super-adsorbents for toxic gases. Heliyon 2019,5 , e01527. [CrossRef] [PubMed]

53. Liang, H.; Nacharaju, P.; Friedman, A.; Friedman, J.M. Nitric oxide generating/releasing materials. Future Sci. OA 2015, 1, FSO54. [CrossRef] [PubMed]

54. Quinn, J.F.; Whittaker, M.R.; Davis, T.P. Delivering nitric oxide with nanoparticles. J. Control. Release 2015, 205, 190-205. [CrossRef]

55. Behera, B.; Vishnu, G.A.; Chatterjee, S.; Sreekumar, N.; Nagabhushan, A.; Rajendran, N.; Prathik, B.; Pandya, H.J. Emerging technologies for antibiotic susceptibility testing. Biosens. Bioelectron. 2019, 142, 111552. [CrossRef]

56. Barani, M.; Bilal, M.; Rahdar, A.; Arshad, R.; Kumar, A.; Hamishekar, H.; Kyzas, G.Z. Nanodiagnosis and nanotreatment of colorectal cancer: An overview. J. Nanopart. Res. 2021, 23, 1-25. [CrossRef]

57. Barani, M.; Bilal, M.; Sabir, F.; Rahdar, A.; Kyzas, G.Z. Nanotechnology in ovarian cancer: Diagnosis and treatment. Life Sci. 2020, 266, 118914. [CrossRef] [PubMed]

58. Barani, M.; Mirzaei, M.; Torkzadeh-Mahani, M.; Nematollahi, M.H. Lawsone-loaded niosome and its antitumor activity in MCF-7 breast cancer cell line: A nano-herbal treatment for cancer. DARU J. Pharm. Sci. 2018, 26, 11-17. [CrossRef]

59. Barani, M.; Mirzaei, M.; Torkzadeh-Mahani, M.; Adeli-Sardou, M. Evaluation of carum-loaded niosomes on breast cancer cells: Physicochemical properties, in vitro cytotoxicity, flow cytometric, DNA fragmentation and cell migration assay. Sci. Rep. 2019, 9, 1-10. [CrossRef] [PubMed]

60. Barani, M.; Mirzaei, M.; Torkzadeh-Mahani, M.; Lohrasbi-Nejad, A.; Nematollahi, M.H. A new formulation of hydrophobin-coated niosome as a drug carrier to cancer cells. Mater. Sci. Eng. C 2020, 113, 110975. [CrossRef] [PubMed]

61. Kwizera, E.A.; O'Connor, R.; Vinduska, V.; Williams, M.; Butch, E.R.; Snyder, S.E.; Chen, X.; Huang, X. Molecular detection and analysis of exosomes using surface-enhanced Raman scattering gold nanorods and a miniaturized device. Theranostics 2018, 8 , 2722. [CrossRef]

62. Song, T.-T.; Wang, W.; Meng, L.-L.; Liu, Y.; Jia, X.-B.; Mao, X. Electrochemical detection of human ferritin based on gold nanorod reporter probe and cotton thread immunoassay device. Chin. Chem. Lett. 2017, 28, 226-230. [CrossRef]

63. Barani, M.; Mukhtar, M.; Rahdar, A.; Sargazi, G.; Thysiadou, A.; Kyzas, G.Z. Progress in the application of nanoparticles and graphene as drug carriers and on the diagnosis of brain infections. Molecules 2021, 26, 186. [CrossRef]

64. Barani, M.; Nematollahi, M.H.; Zaboli, M.; Mirzaei, M.; Torkzadeh-Mahani, M.; Pardakhty, A.; Karam, G.A. In silico and in vitro study of magnetic niosomes for gene delivery: The effect of ergosterol and cholesterol. Mater. Sci. Eng. C 2019, 94, 234-246. [CrossRef] [PubMed]

65. Barani, M.; Sabir, F.; Rahdar, A.; Arshad, R.; Z Kyzas, G. Nanotreatment and nanodiagnosis of prostate cancer: Recent updates. Nanomaterials 2020, 10, 1696. [CrossRef] [PubMed]

66. Barani, M.; Torkzadeh-Mahani, M.; Mirzaei, M.; Nematollahi, M.H. Comprehensive evaluation of gene expression in negative and positive trigger-based targeting niosomes in HEK-293 cell line. Iran. J. Pharm. Res. IJPR 2020, $19,166$.

67. Bilal, M.; Barani, M.; Sabir, F.; Rahdar, A.; Kyzas, G.Z. Nanomaterials for the treatment and diagnosis of Alzheimer's disease: An overview. NanoImpact 2020, 20, 100251. [CrossRef]

68. Zheng, L.; Cai, G.; Wang, S.; Liao, M.; Li, Y.; Lin, J. A microfluidic colorimetric biosensor for rapid detection of Escherichia coli O157: H7 using gold nanoparticle aggregation and smart phone imaging. Biosens. Bioelectron. 2019, 124, 143-149. [CrossRef]

69. Russell, C.; Welch, K.; Jarvius, J.; Cai, Y.; Brucas, R.; Nikolajeff, F.; Svedlindh, P.; Nilsson, M. Gold nanowire based electrical DNA detection using rolling circle amplification. ACS Nano 2014, 8, 1147-1153. [CrossRef]

70. Das, S.S.; Bharadwaj, P.; Bilal, M.; Barani, M.; Rahdar, A.; Taboada, P.; Bungau, S.; Kyzas, G.Z. Stimuli-responsive polymeric nanocarriers for drug delivery, imaging, and theragnosis. Polymers 2020, 12, 1397. [CrossRef] [PubMed]

71. Davarpanah, F.; Yazdi, A.K.; Barani, M.; Mirzaei, M.; Torkzadeh-Mahani, M. Magnetic delivery of antitumor carboplatin by using PEGylated-Niosomes. DARU J. Pharm. Sci. 2018, 26, 57-64. [CrossRef] [PubMed]

72. Ebrahimi, A.K.; Barani, M.; Sheikhshoaie, I. Fabrication of a new superparamagnetic metal-organic framework with core-shell nanocomposite structures: Characterization, biocompatibility, and drug release study. Mater. Sci. Eng. C 2018, 92, 349-355. [CrossRef] [PubMed]

73. Finucane, T.E. “Urinary tract infection”-Requiem for a heavyweight. J. Am. Geriatr. Soc. 2017, 65, 1650-1655. [CrossRef] [PubMed]

74. Okarska-Napierała, M.; Wasilewska, A.; Kuchar, E. Urinary tract infection in children: Diagnosis, treatment, imaging-Comparison of current guidelines. J. Pediatr. Urol. 2017, 13, 567-573. [CrossRef] [PubMed] 
75. Thomas-White, K.J.; Gao, X.; Lin, H.; Fok, C.S.; Ghanayem, K.; Mueller, E.R.; Dong, Q.; Brubaker, L.; Wolfe, A.J. Urinary microbes and postoperative urinary tract infection risk in urogynecologic surgical patients. Int. Urogynecol. J. 2018, 29, $1797-1805$. [CrossRef] [PubMed]

76. Behzadi, P.; Behzadi, E.; Pawlak-Adamska, E.A. Urinary tract infections (UTIs) or genital tract infections (GTIs)? It's the diagnostics that count. GMS Hyg. Infect. Control 2019. [CrossRef]

77. Davenport, M.; Mach, K.E.; Shortliffe, L.M.D.; Banaei, N.; Wang, T.-H.; Liao, J.C. New and developing diagnostic technologies for urinary tract infections. Nat. Rev. Urol. 2017, 14, 296-310. [CrossRef] [PubMed]

78. Kranz, J.; Schmidt, S.; Lebert, C.; Schneidewind, L.; Mandraka, F.; Kunze, M.; Helbig, S.; Vahlensieck, W.; Naber, K.; Schmiemann, G. The 2017 update of the German clinical guideline on epidemiology, diagnostics, therapy, prevention, and management of uncomplicated urinary tract infections in adult patients. Part II: Therapy and prevention. Urol. Int. 2018, 100, 271-278. [CrossRef]

79. Claeys, K.C.; Blanco, N.; Morgan, D.J.; Leekha, S.; Sullivan, K.V. Advances and challenges in the diagnosis and treatment of urinary tract infections: The need for diagnostic stewardship. Curr. Infect. Dis. Rep. 2019, 21, 11. [CrossRef] [PubMed]

80. Coulthard, M.G. Using urine nitrite sticks to test for urinary tract infection in children aged < 2 years: A meta-analysis. Pediatr. Nephrol. 2019, 34, 1283-1288.

81. Masajtis-Zagajewska, A.; Nowicki, M. New markers of urinary tract infection. Clin. Chim. Acta 2017, 471, 286-291. [CrossRef]

82. Taylor, R.A.; Moore, C.L.; Cheung, K.-H.; Brandt, C. Predicting urinary tract infections in the emergency department with machine learning. PLOS ONE 2018, 13, e0194085. [CrossRef]

83. Chu, C.M.; Lowder, J.L. Diagnosis and treatment of urinary tract infections across age groups. Am. J. Obstet. Gynecol. 2018, 219, 40-51. [CrossRef] [PubMed]

84. Rubab, M.; Shahbaz, H.M.; Olaimat, A.N.; Oh, D.-H. Biosensors for rapid and sensitive detection of Staphylococcus aureus in food. Biosens. Bioelectron. 2018, 105, 49-57. [CrossRef] [PubMed]

85. Nasseri, B.; Soleimani, N.; Rabiee, N.; Kalbasi, A.; Karimi, M.; Hamblin, M.R. Point-of-care microfluidic devices for pathogen detection. Biosens. Bioelectron. 2018, 117, 112-128. [CrossRef] [PubMed]

86. Kishimoto, M.; Tsuchiaka, S.; Rahpaya, S.S.; Hasebe, A.; Otsu, K.; Sugimura, S.; Kobayashi, S.; Komatsu, N.; Nagai, M.; Omatsu, T. Development of a one-run real-time PCR detection system for pathogens associated with bovine respiratory disease complex. $J$. Vet. Med. Sci. 2017, 79, 517-523. [CrossRef]

87. Hong, D.K.; Blauwkamp, T.A.; Kertesz, M.; Bercovici, S.; Truong, C.; Banaei, N. Liquid biopsy for infectious diseases: Sequencing of cell-free plasma to detect pathogen DNA in patients with invasive fungal disease. Diagn. Microbiol. Infect. Dis. 2018, 92, 210-213. [CrossRef]

88. Caracciolo, G.; Vali, H.; Moore, A.; Mahmoudi, M. Challenges in molecular diagnostic research in cancer nanotechnology. Nano Today 2019, 27, 6-10. [CrossRef]

89. Syedmoradi, L.; Daneshpour, M.; Alvandipour, M.; Gomez, F.A.; Hajghassem, H.; Omidfar, K. Point of care testing: The impact of nanotechnology. Biosens. Bioelectron. 2017, 87, 373-387. [CrossRef] [PubMed]

90. Padil, V.V.; Wacławek, S.; Černík, M.; Varma, R.S. Tree gum-based renewable materials: Sustainable applications in nanotechnology, biomedical and environmental fields. Biotechnol. Adv. 2018, 36, 1984-2016. [CrossRef]

91. Chen, X.-J.; Zhang, X.-Q.; Liu, Q.; Zhang, J.; Zhou, G. Nanotechnology: A promising method for oral cancer detection and diagnosis. J. Nanobiotechnol. 2018, 16, 52. [CrossRef]

92. Arca-Lafuente, S.; Martínez-Román, P.; Mate-Cano, I.; Madrid, R.; Briz, V. Nanotechnology: A reality for diagnosis of HCV infectious disease. J. Infect. 2020, 80, 8-15. [CrossRef]

93. Kumar, M.S.; Ghosh, S.; Nayak, S.; Das, A.P. Recent advances in biosensor based diagnosis of urinary tract infection. Biosens. Bioelectron. 2016, 80, 497-510. [CrossRef] [PubMed]

94. Singh, L.; Kruger, H.G.; Maguire, G.E.; Govender, T.; Parboosing, R. The role of nanotechnology in the treatment of viral infections. Ther. Adv. Infect. Dis. 2017, 4, 105-131. [CrossRef] [PubMed]

95. Vasudevan, S.; Srinivasan, P.; Rayappan, J.B.B.; Solomon, A.P. A photoluminescence biosensor for the detection of N-acyl homoserine lactone using cysteamine functionalized $\mathrm{ZnO}$ nanoparticles for the early diagnosis of urinary tract infections. J. Mater. Chem. B 2020, 8, 4228-4236. [CrossRef] [PubMed]

96. Myndrul, V.; Coy, E.; Bechelany, M.; Iatsunskyi, I. Photoluminescence label-free immunosensor for the detection of Aflatoxin B1 using polyacrylonitrile/zinc oxide nanofibers. Mater. Sci. Eng. C 2021, 118, 111401. [CrossRef] [PubMed]

97. Myndrul, V.; Viter, R.; Savchuk, M.; Shpyrka, N.; Erts, D.; Jevdokimovs, D.; Silamikelis, V.; Smyntyna, V.; Ramanavicius, A.; Iatsunskyi, I. Porous silicon based photoluminescence immunosensor for rapid and highly-sensitive detection of Ochratoxin A. Biosens. Bioelectron. 2018, 102, 661-667. [CrossRef]

98. Kalyani, N.; Goel, S.; Jaiswal, S. On-site sensing of pesticides using point-of-care biosensors: A review. Environ. Chem. Lett. 2020, 19, 345-354. [CrossRef]

99. Yang, D.; Zhou, H.; Dina, N.E.; Haisch, C. Portable bacteria-capturing chip for direct surface-enhanced Raman scattering identification of urinary tract infection pathogens. R. Soc. Open Sci. 2018, 5, 180955. [CrossRef]

100. Alhogail, S.; Suaifan, G.A.; Bikker, F.J.; Kaman, W.E.; Weber, K.; Cialla-May, D.; Popp, J.r.; Zourob, M.M. Rapid colorimetric detection of Pseudomonas aeruginosa in clinical isolates using a magnetic nanoparticle biosensor. ACS Omega 2019, 4, 21684-21688. [CrossRef] 
101. Michael, I.; Kim, D.; Gulenko, O.; Kumar, S.; Kumar, S.; Clara, J.; Ki, D.Y.; Park, J.; Jeong, H.Y.; Kim, T.S. A fidget spinner for the point-of-care diagnosis of urinary tract infection. Nat. Biomed. Eng. 2020, 4, 591-600. [CrossRef]

102. Adrover-Jaume, C.; Rojo-Molinero, E.; Clemente, A.; Russell, S.M.; Arranz, J.; Oliver, A.; de la Rica, R. Mobile origami immunosensors for the rapid detection of urinary tract infections. Analyst 2020, 145, 7916-7921. [CrossRef] [PubMed]

103. Monošík, R.; Stred'anský, M.; Šturdík, E. Application of electrochemical biosensors in clinical diagnosis. J. Clin. Lab. Anal. 2012, 26, 22-34. [CrossRef] [PubMed]

104. Kharati, M.; Foroutanparsa, S.; Rabiee, M.; Salarian, R.; Rabiee, N.; Rabiee, G. Early diagnosis of multiple sclerosis based on optical and electrochemical biosensors: Comprehensive perspective. Curr. Anal. Chem. 2020, 16, 557-569. [CrossRef]

105. Pan, Y.; Sonn, G.A.; Sin, M.L.; Mach, K.E.; Shih, M.-C.; Gau, V.; Wong, P.K.; Liao, J.C. Electrochemical immunosensor detection of urinary lactoferrin in clinical samples for urinary tract infection diagnosis. Biosens. Bioelectron. 2010, 26, 649-654. [CrossRef]

106. Arao, S.; Matsuura, S.; Nonomura, M.; Miki, K.; Kabasawa, K.; Nakanishi, H. Measurement of urinary lactoferrin as a marker of urinary tract infection. J. Clin. Microbiol. 1999, 37, 553-557. [CrossRef]

107. Chen, C.; Wu, Y.; Dong, T. Dipsticks integrated on smart diapers for colorimetric analysis of urinary tract infections in the field. In Proceedings of the 16th International Conference on Mechatronics-Mechatronika 2014, Brno, Czech Republic, 3-5 December 2014; pp. 423-427.

108. Ho, M.-L.; Liu, W.-F.; Tseng, H.-Y.; Yeh, Y.-T.; Tseng, W.-T.; Chou, Y.-Y.; Huang, X.-R.; Hsu, H.-C.; Ho, L.-I.; Pan, S.-W. Quantitative determination of leukocyte esterase with a paper-based device. RSC Adv. 2020, 10, 27042-27049. [CrossRef]

109. Nair, S.; Gomez-Cruz, J.; Manjarrez-Hernandez, Á.; Ascanio, G.; Sabat, R.G.; Escobedo, C. Rapid label-free detection of intact pathogenic bacteria in situ via surface plasmon resonance imaging enabled by crossed surface relief gratings. Analyst 2020, 145, 2133-2142. [CrossRef]

110. Brayner, R.; Ferrari-Iliou, R.; Brivois, N.; Djediat, S.; Benedetti, M.F.; Fiévet, F. Toxicological impact studies based on Escherichia coli bacteria in ultrafine $\mathrm{ZnO}$ nanoparticles colloidal medium. Nano Lett. 2006, 6, 866-870. [CrossRef]

111. Ashmore, D.A.; Chaudhari, A.; Barlow, B.; Barlow, B.; Harper, T.; Vig, K.; Miller, M.; Singh, S.; Nelson, E.; Pillai, S. Evaluation of E. coli inhibition by plain and polymer-coated silver nanoparticles. Rev. Do Inst. Med. Trop. São Paulo 2018, 6, e18. [CrossRef]

112. Wang, L.; Yang, J.; Yang, X.; Hou, Q.; Liu, S.; Zheng, W.; Long, Y.; Jiang, X. Mercaptophenylboronic acid-activated gold nanoparticles as nanoantibiotics against multidrug-resistant bacteria. ACS Appl. Mater. Interfaces 2020, 12, 51148-51159. [CrossRef] [PubMed]

113. Shaikh, S.; Nazam, N.; Rizvi, S.M.D.; Ahmad, K.; Baig, M.H.; Lee, E.J.; Choi, I. Mechanistic insights into the antimicrobial actions of metallic nanoparticles and their implications for multidrug resistance. Int. J. Mol. Sci. 2019, 20, 2468. [CrossRef]

114. Mittal, R.; Pan, D.R.; Parrish, J.M.; Huang, E.H.; Yang, Y.; Patel, A.P.; Malhotra, A.K.; Mittal, J.; Chhibber, S.; Harjai, K. Local drug delivery in the urinary tract: Current challenges and opportunities. J. Drug Target. 2018, 26, 658-669. [CrossRef]

115. Amini, S.M. Preparation of antimicrobial metallic nanoparticles with bioactive compounds. Mater. Sci. Eng. C 2019, 103, 109809. [CrossRef]

116. Aderibigbe, B.A. Metal-based nanoparticles for the treatment of infectious diseases. Molecules 2017, 22, 1370. [CrossRef]

117. Rahdar, A.; Hajinezhad, M.R.; Nasri, S.; Beyzaei, H.; Barani, M.; Trant, J.F. The synthesis of methotrexate-loaded F127 microemulsions and their in vivo toxicity in a rat model. J. Mol. Liq. 2020, 313, 113449. [CrossRef]

118. Rahdar, A.; Hajinezhad, M.R.; Sargazi, S.; Barani, M.; Bilal, M.; Kyzas, G.Z. Deferasirox-loaded pluronic nanomicelles: Synthesis, characterization, in vitro and in vivo studies. J. Mol. Liq. 2021, 323, 114605. [CrossRef]

119. Rahdar, A.; Hajinezhad, M.R.; Sargazi, S.; Bilal, M.; Barani, M.; Karimi, P.; Kyzas, G.Z. Biochemical effects of deferasirox and deferasirox-loaded nanomicellesin iron-intoxicated rats. Life Sci. 2021, 270, 119146. [CrossRef] [PubMed]

120. Rahdar, A.; Taboada, P.; Hajinezhad, M.R.; Barani, M.; Beyzaei, H. Effect of tocopherol on the properties of Pluronic F127 microemulsions: Physico-chemical characterization and in vivo toxicity. J. Mol. Liq. 2019, 277, 624-630. [CrossRef]

121. Sabir, F.; Barani, M.; Rahdar, A.; Bilal, M.; Nadeem, M. How to face skin cancer with nanomaterials: A review. Biointerface Res. Appl. Chem. 2021, 11, 11931-11955.

122. Torkzadeh-Mahani, M.; Zaboli, M.; Barani, M.; Torkzadeh-Mahani, M. A combined theoretical and experimental study to improve the thermal stability of recombinant D lactate dehydrogenase immobilized on a novel superparamagnetic Fe3O4NPs@ metal-organic framework. Appl. Organomet. Chem. 2020, 34, e5581. [CrossRef]

123. Chandra, H.; Kumari, P.; Bontempi, E.; Yadav, S. Medicinal plants: Treasure trove for green synthesis of metallic nanoparticles and their biomedical applications. Biocatal. Agric. Biotechnol. 2020, 24, 101518. [CrossRef]

124. Al-Ansari, M.M.; Dhasarathan, P.; Ranjitsingh, A.; Al-Humaid, L.A. Challenging multidrug-resistant urinary tract bacterial isolates via bio-inspired synthesis of silver nanoparticles using the inflorescence extracts of Tridax procumbens. J. King Saud Univ. Sci. 2020, 32, 3145-3152. [CrossRef]

125. Divya, M.; Kiran, G.S.; Hassan, S.; Selvin, J. Biogenic synthesis and effect of silver nanoparticles (AgNPs) to combat catheter-related urinary tract infections. Biocatal. Agric. Biotechnol. 2019, 18, 101037. [CrossRef]

126. Saleh, T.H.; Hashim, S.T.; Malik, S.N.; AL-Rubaii, B.A.L. Down-regulation of flil gene expression by $\mathrm{Ag}$ nanoparticles and TiO 2 nanoparticles in pragmatic clinical isolates of Proteus mirabilis and Proteus vulgaris from urinary tract infection. Nano Biomed. Eng. 2019, 11, 321-332. [CrossRef] 
127. Das, P.; Kumar, K.; Nambiraj, A.; Awasthi, R.; Dua, K.; Malipeddi, H. Antibacterial and in vitro growth inhibition study of struvite urinary stones using Oxalis corniculata Linn. leaf extract and its biofabricated silver nanoparticles. Recent Pat. Drug Deliv. Formul. 2018, 12, 170-178. [CrossRef] [PubMed]

128. Bhargava, A.; Pareek, V.; Roy Choudhury, S.; Panwar, J.; Karmakar, S. Superior bactericidal efficacy of fucose-functionalized silver nanoparticles against Pseudomonas aeruginosa PAO1 and prevention of its colonization on urinary catheters. ACS Appl. Mater. Interfaces 2018, 10, 29325-29337. [CrossRef]

129. Lopez-Carrizales, M.; Velasco, K.I.; Castillo, C.; Flores, A.; Magaña, M.; Martinez-Castanon, G.A.; Martinez-Gutierrez, F. In vitro synergism of silver nanoparticles with antibiotics as an alternative treatment in multiresistant uropathogens. Antibiotics 2018, 7, 50. [CrossRef]

130. El-Batal, A.I.; El-Sayyad, G.S.; Al-Hazmi, N.E.; Gobara, M. Antibiofilm and antimicrobial activities of silver boron nanoparticles synthesized by PVP polymer and gamma rays against urinary tract pathogens. J. Clust. Sci. 2019, 30, 947-964. [CrossRef]

131. Mishra, M.P.; Padhy, R.N. Antibacterial activity of green silver nanoparticles synthesized from Anogeissus acuminata against multidrug resistant urinary tract infecting bacteria in vitro and host-toxicity testing. J. Appl. Biomed. 2018, 16, 120-125. [CrossRef]

132. Rodríguez-Serrano, C.; Guzmán-Moreno, J.; Ángeles-Chávez, C.; Rodríguez-González, V.; Ortega-Sigala, J.J.; Ramírez-Santoyo, R.M.; Vidales-Rodríguez, L.E. Biosynthesis of silver nanoparticles by Fusarium scirpi and its potential as antimicrobial agent against uropathogenic Escherichia coli biofilms. PLoS ONE 2020, 15, e0230275. [CrossRef] [PubMed]

133. Mala, R.; Aglin, A.A.; Celsia, A.S.R.; Geerthika, S.; Kiruthika, N.; VazagaPriya, C.; Kumar, K.S. Foley catheters functionalised with a synergistic combination of antibiotics and silver nanoparticles resist biofilm formation. IET Nanobiotechnol. 2017, 11, 612-620. [CrossRef] [PubMed]

134. Shafreen, R.B.; Seema, S.; Ahamed, A.P.; Thajuddin, N.; Alharbi, S.A. Inhibitory effect of biosynthesized silver nanoparticles from extract of Nitzschia palea against curli-mediated biofilm of Escherichia coli. Appl. Biochem. Biotechnol. 2017, 183, 1351-1361. [CrossRef] [PubMed]

135. Valsalam, S.; Agastian, P.; Arasu, M.V.; Al-Dhabi, N.A.; Ghilan, A.-K.M.; Kaviyarasu, K.; Ravindran, B.; Chang, S.W.; Arokiyaraj, S. Rapid biosynthesis and characterization of silver nanoparticles from the leaf extract of Tropaeolum majus L. and its enhanced in-vitro antibacterial, antifungal, antioxidant and anticancer properties. J. Photochem. Photobiol. B Biol. 2019, 191, 65-74. [CrossRef] [PubMed]

136. Al-Enizi, A.M.; Ahamad, T.; Al-Hajji, A.B.; Ahmed, J.; Chaudhary, A.A.; Alshehri, S.M. Cellulose gum and copper nanoparticles based hydrogel as antimicrobial agents against urinary tract infection (UTI) pathogens. Int. J. Biol. Macromol. 2018, 109, 803-809. [CrossRef]

137. Shalom, Y.; Perelshtein, I.; Perkas, N.; Gedanken, A.; Banin, E. Catheters coated with Zn-doped CuO nanoparticles delay the onset of catheter-associated urinary tract infections. Nano Res. 2017, 10, 520-533. [CrossRef]

138. Muslim, D.S.N.; Dham, Z.A.; Mohammed, D.N.J. Synthesis and characterization of nanoparticles conjugated tannase and using it for enhancement of antibacterial activity of tannase produced by Serratia marcescens. Microb. Pathog. 2017, 110, 484-493. [CrossRef]

139. Santhoshkumar, J.; Kumar, S.V.; Rajeshkumar, S. Synthesis of zinc oxide nanoparticles using plant leaf extract against urinary tract infection pathogen. Resour. Effic. Technol. 2017, 3, 459-465. [CrossRef]

140. Abd Elkodous, M.; El-Sayyad, G.S.; Mia, A.M.; Abdelrahman, I.Y.; Mosallam, F.M.; Gobara, M.; El-Batal, A.I. Fabrication of ultra-pure anisotropic zinc oxide nanoparticles via simple and cost-effective route: Implications for UTI and EAC medications. Biol. Trace Elem. Res. 2019, 196, 297-317. [CrossRef]

141. Tiwari, V.; Mishra, N.; Gadani, K.; Solanki, P.S.; Shah, N.; Tiwari, M. Mechanism of anti-bacterial activity of zinc oxide nanoparticle against carbapenem-resistant Acinetobacter baumannii. Front. Microbiol. 2018, 9, 1218. [CrossRef]

142. El-Rab, S.M.; Abo-Amer, A.E.; Asiri, A.M. Biogenic synthesis of ZnO nanoparticles and its potential use as antimicrobial agent against multidrug-resistant pathogens. Curr. Microbiol. 2020, 77, 1767-1779. [CrossRef] [PubMed]

143. Hosseini, S.S.; Ghaemi, E.; Noroozi, A.; Niknejad, F. Zinc oxide nanoparticles inhibition of initial adhesion and ALS1 and ALS3 gene expression in Candida albicans strains from urinary tract infections. Mycopathologia 2019, 184, 261-271. [CrossRef] [PubMed]

144. Hosseini, S.S.; Ghaemi, E.; Koohsar, F. Influence of $\mathrm{ZnO}$ nanoparticles on Candida albicans isolates biofilm formed on the urinary catheter. Iran. J. Microbiol. 2018, 10, 424. [PubMed]

145. El-Sayyad, G.S.; El-Bastawisy, H.S.; Gobara, M.; El-Batal, A.I. Gentamicin-assisted mycogenic selenium nanoparticles synthesized under gamma irradiation for robust reluctance of resistant urinary tract infection-causing pathogens. Biol. Trace Elem. Res. 2019, 195, 323-342. [CrossRef] [PubMed]

146. Paralikar, P.; Ingle, A.P.; Tiwari, V.; Golinska, P.; Dahm, H.; Rai, M. Evaluation of antibacterial efficacy of sulfur nanoparticles alone and in combination with antibiotics against multidrug-resistant uropathogenic bacteria. J. Environ. Sci. Health Part A 2019, 54, 381-390. [CrossRef]

147. Park, S.-C.; Kim, Y.-M.; Lee, J.-K.; Kim, N.-H.; Kim, E.-J.; Heo, H.; Lee, M.-Y.; Lee, J.R.; Jang, M.-K. Targeting and synergistic action of an antifungal peptide in an antibiotic drug-delivery system. J. Control. Release 2017, 256, 46-55. [CrossRef]

148. Dayyoub, E.; Frant, M.; Pinnapireddy, S.R.; Liefeith, K.; Bakowsky, U. Antibacterial and anti-encrustation biodegradable polymer coating for urinary catheter. Int. J. Pharm. 2017, 531, 205-214. [CrossRef] 
149. Brauner, B.; Semmler, J.; Rauch, D.; Nokaj, M.; Haiss, P.; Schwarz, P.; Wirth, M.; Gabor, F. Trimethoprim-loaded PLGA nanoparticles grafted with WGA as potential intravesical therapy of urinary tract infections-Studies on adhesion to SV-HUCs under varying time, $\mathrm{pH}$, and drug-loading conditions. ACS Omega 2020, 5, 17377-17384. [CrossRef]

150. Ludwig, D.B.; de Camargo, L.E.A.; Khalil, N.M.; Auler, M.E.; Mainardes, R.M. Antifungal activity of chitosan-coated poly (lactic-co-glycolic) acid nanoparticles containing amphotericin B. Mycopathologia 2018, 183, 659-668. [CrossRef]

151. Sharma, K.; Bose, S.K.; Chhibber, S.; Harjai, K. Exploring the therapeutic efficacy of zingerone nanoparticles in treating biofilmassociated pyelonephritis caused by Pseudomonas aeruginosa in the murine model. Inflammation 2020, 43, 2344-2356. [CrossRef] [PubMed]

152. Gao, L.; Wang, Y.; Li, Y.; Xu, M.; Sun, G.; Zou, T.; Wang, F.; Xu, S.; Da, J.; Wang, L. Biomimetic biodegradable Ag@ Au nanoparticleembedded ureteral stent with a constantly renewable contact-killing antimicrobial surface and antibiofilm and extraction-free properties. Acta Biomater. 2020, 114, 117-132. [CrossRef] [PubMed]

153. Tiwari, M.; Kumar, P.; Tejavath, K.K.; Tiwari, V. Assessment of molecular mechanism of gallate-polyvinylpyrrolidone-capped hybrid silver nanoparticles against carbapenem-resistant Acinetobacter baumannii. ACS Omega 2020, 5, 1206-1213. [CrossRef] [PubMed]

154. Lopes, L.Q.S.; de Almeida Vaucher, R.; Giongo, J.L.; Gündel, A.; Santos, R.C.V. Characterisation and anti-biofilm activity of glycerol monolaurate nanocapsules against Pseudomonas aeruginosa. Microb. Pathog. 2019, 130, 178-185. [CrossRef]

155. Lu, D.; Tao, R.; Wang, Z. Carbon-based materials for photodynamic therapy: A mini-review. Front. Chem. Sci. Eng. 2019, 13, 310-323. [CrossRef]

156. Dybowska-Sarapuk, Ł.; Kotela, A.; Krzemiński, J.; Wróblewska, M.; Marchel, H.; Romaniec, M.; Łegosz, P.; Jakubowska, M. Graphene nanolayers as a new method for bacterial biofilm prevention: Preliminary results. J. AOAC Int. 2017, 100, 900-904. [CrossRef]

157. Rouhani, P.; Singh, R.N. Polyethyleneimine-functionalized magnetic $\mathrm{Fe}_{3} \mathrm{O}_{4}$ and nanodiamond particles as a platform for amoxicillin delivery. J. Nanosci. Nanotechnol. 2020, 20, 3957-3970. [CrossRef] [PubMed]

158. Iyer, J.K.; Dickey, A.; Rouhani, P.; Kaul, A.; Govindaraju, N.; Singh, R.N.; Kaul, R. Nanodiamonds facilitate killing of intracellular uropathogenic E. coli in an in vitro model of urinary tract infection pathogenesis. PLoS ONE 2018, 13, e0191020. [CrossRef] [PubMed]

159. Sehad, C.; Shiao, T.C.; Sallam, L.M.; Azzouz, A.; Roy, R. Effect of dendrimer generation and aglyconic linkers on the binding properties of mannosylated dendrimers prepared by a combined convergent and onion peel approach. Molecules 2018, 23, 1890. [CrossRef]

160. Zhu, Z.; Yu, F.; Chen, H.; Wang, J.; Lopez, A.I.; Chen, Q.; Li, S.; Long, Y.; Darouiche, R.O.; Hull, R.A. Coating of silicone with mannoside-PAMAM dendrimers to enhance formation of non-pathogenic Escherichia coli biofilms against colonization of uropathogens. Acta Biomater. 2017, 64, 200-210. [CrossRef] [PubMed]

161. Agnihotri, S.; Dhiman, N.K. Development of nano-antimicrobial biomaterials for biomedical applications. In Advances in Biomaterials for Biomedical Applications; Springer: Berlin/Heidelberg, Germany, 2017; pp. 479-545.

162. Dutta, R.; Nenavathu, B.P.; Gangishetty, M.K.; Reddy, A. Antibacterial effect of chronic exposure of low concentration ZnO nanoparticles on E. coli. J. Environ. Sci. Health Part A 2013, 48, 871-878. [CrossRef] [PubMed]

163. Andersen, T.; Mishchenko, E.; Flaten, G.E.; Sollid, J.U.E.; Mattsson, S.; Tho, I.; Škalko-Basnet, N. Chitosan-based nanomedicine to fight genital candida infections: Chitosomes. Mar. Drugs 2017, 15, 64. [CrossRef] [PubMed]

164. Polívková, M.; Hubáček, T.; Staszek, M.; Švorčík, V.; Siegel, J. Antimicrobial treatment of polymeric medical devices by silver nanomaterials and related technology. Int. J. Mol. Sci. 2017, 18, 419. [CrossRef] [PubMed] 